2015

EXAMINING POLICY CAPACITY INITIATIVES WITHIN CLIMATE CHANGE FRAMEWORKS IN THREE US AND CANADIAN SECTORS USING NVIVO CONTENT ANALYSIS

Mehjabeen Rahman

Michigan Technological University

Follow this and additional works at: https://digitalcommons.mtu.edu/etds

Part of the Energy Policy Commons, and the Environmental Policy Commons Copyright 2015 Mehjabeen Rahman

Recommended Citation

Rahman, Mehjabeen, "EXAMINING POLICY CAPACITY INITIATIVES WITHIN CLIMATE CHANGE FRAMEWORKS IN THREE US AND CANADIAN SECTORS USING NVIVO CONTENT ANALYSIS", Master'S report, Michigan Technological University, 2015.

https://doi.org/10.37099/mtu.dc.etds/927

Follow this and additional works at: https://digitalcommons.mtu.edu/etds

Part of the Energy Policy Commons, and the Environmental Policy Commons 


\title{
EXAMINING POLICY CAPACITY INITIATIVES WITHIN CLIMATE CHANGE FRAMEWORKS IN THREE US AND CANADIAN SECTORS USING NVIVO CONTENT ANALYSIS
}

\author{
By \\ Mehjabeen Rahman
}

\author{
A REPORT \\ Submitted in partial fulfillment of the requirements for the degree of \\ MASTER OF SCIENCE \\ In Environmental and Energy Policy \\ MICHIGAN TECHNOLOGICAL UNIVERSITY \\ 2015 \\ (C) 2015 Mehjabeen Rahman
}


This report has been approved in partial fulfillment of the requirements for the Degree of MASTER OF SCIENCE in Environmental and Energy Policy

Department of Social Sciences

Report Advisor: Dr. Adam M. Wellstead

Committee Member: Dr. Andrew J. Burton

Committee Member: Dr. Hugh S. Gorman

Department Chair: $\quad$ Dr. Patrick E. Martin 


\section{Contents}

Acknowledgements.................................................................................................... viii

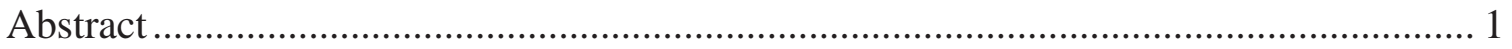

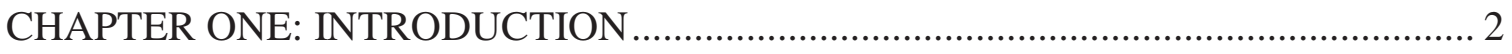

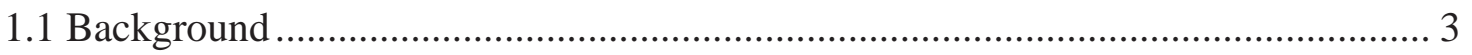

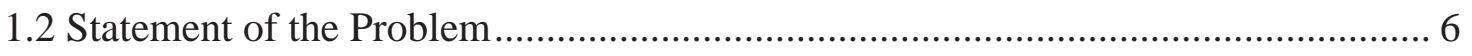

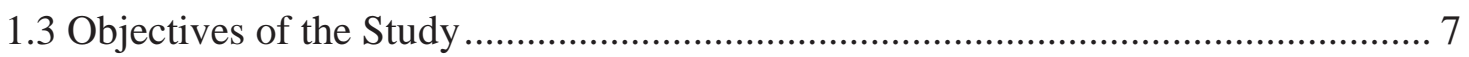

CHAPTER TWO: LITERATURE REVIEW ............................................................... 8

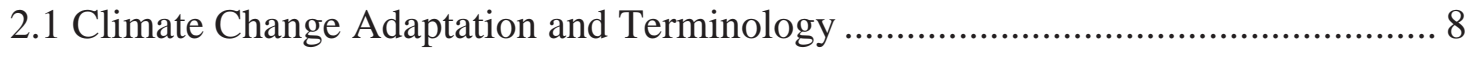

2.2 Climate Change Adaptation Frameworks ................................................................. 13

2.3 Climate Change Adaptation and Policy .................................................................. 16

2.4 Different Types of Policy Capacity ......................................................................... 18

2.5 The use of Nvivo in Qualitative research in the social sciences ............................. 21

CHAPTER THREE: DATA AND METHODS .......................................................... 22

3.1 Collection and Inclusion/Exclusion Criteria.............................................................. 26

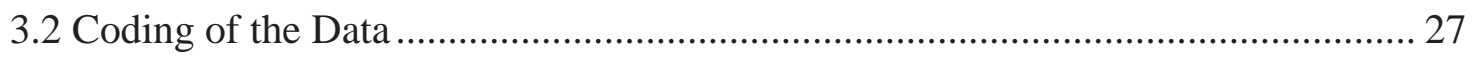

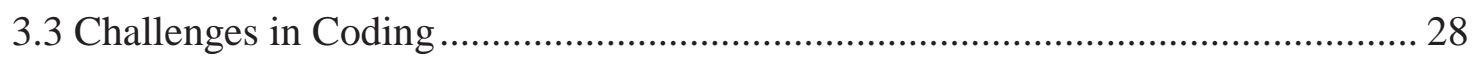

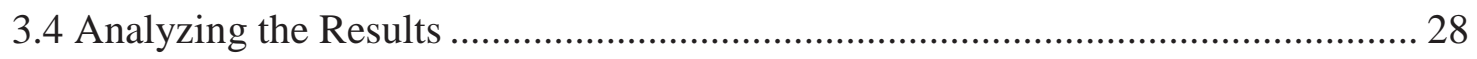

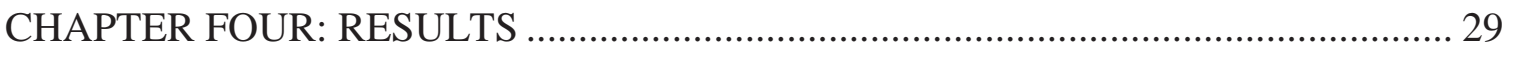

4.1 General Trends in Data .................................................................................. 29

4.2 Comparing US and Canadian Data ....................................................................... 33

4.3 Sectors Represented by Frameworks Which Mention Policy Capacity ................... 36

4.4 Relationships within the Different Types of Policy Capacity ………..................... 37

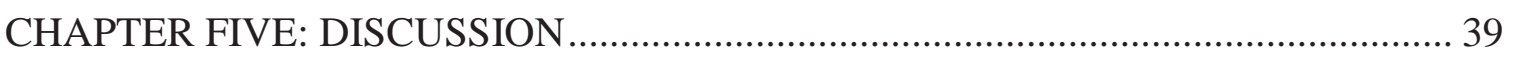


CHAPTER SIX: POLICY IMPLICATIONS

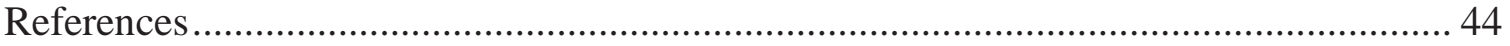




\section{List of Figures}

Figure 1: A framework of policy capacity typologies .................................................... 20

Figure 2: The process of content analysis adapted from Krippendorff 1989 ................... 23

Figure 3: The three types of content analysis and the method of content analysis used.

Using information from Elo and Kyngas, 2008, and Hsieh and Shannon, 2005.............. 26

Figure 4: Tree diagram created within NVivo representing frequency of occurrence of

policy capacity initiatives in literature .............................................................................. 33

Figure 5: Representation by country of the 84 frameworks on which the first step of the search was done

Figure 6: Pie charts illustrating the source of the 84 frameworks from the three different

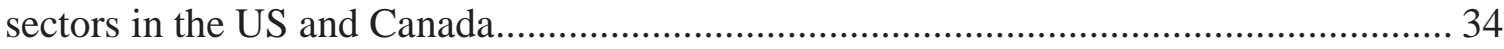

Figure 7: Country distribution of frameworks and assessments which refer to policy

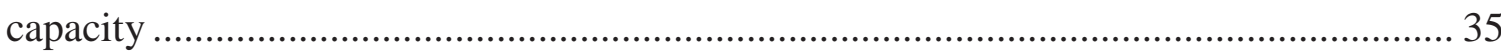

Figure 8: Number of references to policy capacity initiatives in the US and Canada ....... 36

Figure 9: Distribution of sectors based on mention of policy capacity ............................. 37

Figure 10: Cluster Diagram of Policy Capacity Types to exhibit relationship between

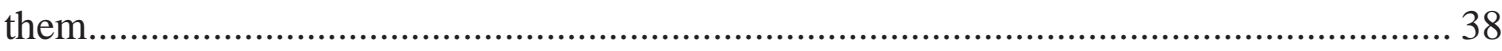




\section{List of Tables}

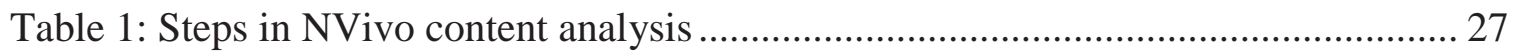

Table 2: Types of policy capacity and references within the frameworks ...................... 30

Table 3: Policy capacity examples from Canadian and US frameworks......................... 31 


\section{List of Appendices}

Appendix A: Canadian Climate Change Assessments and Plans 50

Appendix B: United States Climate Change Assessments and Plans 56

Appendix C: NVivo screenshots 60 


\section{Acknowledgements}

First, I would like to appreciate the efforts of my advisor, Dr. Adam Wellstead, without whom this project would have been impossible for me to complete. This research was

done as part of Dr. Wellstead's project funded by the MTU Research Excellence Fund. I am grateful to Dr. Andrew Burton and Dr. Hugh Gorman, for taking the time to serve on my report committee. I would like to thank Samantha Whitens who carried out the original collection and categorization of the data and did an exemplary job which made my coding process much more efficient; Amy Spahn who helped me with the logistics of my defense; and my husband, who helped me carry out the formatting and data presentation seen within the report. 


\section{Abstract}

The climate change narrative has changed from one of mitigation to one of adaptation. Governments around the world have created climate change frameworks which address how the country can better cope with the expected and unexpected changes due to global climate change. In an effort to do so, federal governments of both Canada and the United States, as well as some provinces and states within these countries, have created detailed documents which outline what steps must be taken to adapt to these changes. However, not much is mentioned about how these steps will be translated in to policy, and how that policy will eventually be implemented. To examine the ability of governments to acknowledge and incorporate the plethora of scientific information to policy, consideration must be made for policy capacity. This report focuses on three sectors: water supply and demand; drought and flood planning; and forest and grassland ecosystems, and the word 'capacity' as related to nine different forms of policy capacity acknowledged in these frameworks. Qualitative content analysis using NVivo was carried out on fifty four frameworks and the results obtained show that there is a greater consideration for managerial capacity compared to analytical or political capacity. The data also indicated that although there were more Canadian frameworks which referred to policy capacity, the frameworks from the United States actually considered policy capacity to a greater degree. 


\section{CHAPTER ONE: INTRODUCTION}

This report highlights findings from research carried out as part of a project funded by the MTU Research Excellence Fund (REF). This report and the research behind it developed preliminary data which can be used to seek external funding to further investigate climate change adaptations and policy capacity and mainstreaming processes in different governmental sectors. This grant was awarded to Dr. Adam M. Wellstead to collect data to support the project "Beyond the Assessment: The Complexity of Climate Change Multi-Level Governance. Trans-boundary Climate Change Policy Challenges in North America's Great Plains" from sources beyond academia. The data collection for this project was carried out directly from government and intergovernmental bodies which are developing strategies and policies to combat ongoing climate change issues.

The sources of data are the climate change adaptation frameworks and assessments which have been proactively created by the various Canadian and US Governments. The search revealed that more Canadian frameworks existed as compared to US frameworks. The list of the 84 different Climate Adaptation Frameworks which will be used for the analysis in this report is provided in Appendices A and B. These include frameworks from federal and provincial governments within Canada and the US, and are from three different sectors: water supply and demand; drought and flood planning; and forest and grassland ecosystems. 


\subsection{Background}

The current scientific consensus towards climate change is that it is happening, and that it is already having a significant impact on climatic conditions and patterns (IPCC, 2014). The trend towards more extreme conditions is expected to intensify as carbon dioxide concentrations in the atmosphere continue to increase (IPCC, 2014). When this issue was first acknowledged as part of the United Nations Framework Convention on Climate Change (UNFCCC) in 1992, the primary method of dealing with it was through mitigation efforts which called for decreasing the levels of greenhouse gas emissions into the atmosphere (Essential Background). However, it was soon evident that climate change was inevitable and that climate change adaptation was a necessary planning goal (Essential Background). As a means to this end, the Kyoto protocol was adopted in 1997 and provided information for both mitigation and adaptation measures (Kyoto Protocol).

According to the latest IPCC report published in 2014, changes in precipitation patterns, changing hydrological systems, and melting permafrost and glaciers are already creating changes in water supply quality and quantity and having a profound impact on the water supply and demand, forest and grassland ecosystems, and drought and flood planning sectors. Additionally, the IPCC asserts with a high level of confidence that extreme events such as droughts, floods, and wildfires, which reveal already existing vulnerabilities within our coping systems, are expected to increase in frequency with higher average temperatures. Freshwater resources in particular are subject to a greater level of concern because of altering systems of renewal and greater pollutant loads (IPCC, 2014). 
Adaptation is often described as a complementary activity to mitigation, and refers to the efforts of analyzing the impacts of climate change and preparing to adapt to these very impacts (Smit and Wandel, 2006). Adaptation to climate change is now considered a necessity to ensure that basic human needs can be met. Strategies include prioritizing food security, preventing disruption of social systems and assuring that livelihoods are not compromised (Adger, 2010; Lobell et al., 2008; Scott et al., 2003). Irrigation, insurance, and weather forecasting are examples of how society has adapted to the pressures of climate change (Adger et al. 2009).

However, to have a greater level of adoption of these adaptation initiatives, integration, or mainstreaming as the literature calls it, into public policy is essential. Mainstreaming is described as the process by which adaptation initiatives are brought in to the policy arena and is highlighted as an essential component of climate change adaptation planning (Smit and Wandel, 2006).

The United Nations Framework Convention on Climate Change (UNFCCC) has been suggesting a movement towards adaptation and mainstreaming since 2000 (Olmos, 2001). The most recent report by the IPCC, the Fifth Assessment Report of the Intergovernmental Panel on Climate Change, contains even more of an emphasis on adaptation in the different sectors such as freshwater and marine ecosystems (IPCC, 2014). Different governments and non-governmental organizations have taken diverse approaches to how mainstreaming should be carried out. The United Nations Development Program (UNDP) has investigated how to integrate climate change into all aspects of policy making, the European Union (EU) has published a green paper on adaptation, and the UK government has developed a comprehensive adaptation policy 
framework (Urwin and Jordan 2007). In North America, various Canadian and American state, province, and federal governments have created such climate change adaptation frameworks and assessments. These frameworks can be considered to be the first stage in the policy process. They address several different climate issues, but there is a strong emphasis on water supply and demand, drought and flood planning, and forest and grassland ecosystems, as these are the sectors which are expected to be most exposed to the dangers of climate change. To translate these climate change adaptation initiatives to policy, existing and future policy capacity must be taken in to consideration especially as these climate issues become even more complicated and stakeholders have higher expectations of governmental units (Wu et al., 2015). However, policy capacity is a complicated issue which is not being taken in to consideration within the climate change literature. Policy capacity can be described as a multi-level, multi-sectoral set of "skills, competences, resources, and institutional arrangements and capabilities with which key tasks and functions in policy process are structured, staffed and supported" (Wu et al., 2015 pp 4). The availability of these arrangements and capabilities are essential to the policy process so that governmental units are able to fully participate in all stages of the policy process (Wu et al., 2015).

There have been numerous documents released by governments, but along with creating such frameworks assessments which address these sectors, it is also important to ensure that these frameworks address ways in which vulnerability may be reduced, adaptive management increased, and that the principles of an evidence based policy environment are followed (Preston, 2011). Within assessments, policy making is often thought of as an automatic response instead of the complicated process that it is, and 
which requires governments to have a level of policy capacity integrated into these frameworks. (Wellstead and Stedman, 2015). In order to analyze these frameworks, content analysis was conducted. This report will address the usage of 'capacity' within these frameworks by employing the NVivo software in order to assess whether they correspond to a taxonomy of policy capacity concepts.

\subsection{Statement of the Problem}

Although there exist many climate change adaptation frameworks, most do not consider the importance of policy capacity. Without translation in to policy, these frameworks, which contain management recommendations and a large volume of knowledge but limited information on developing and implementing policy options, do not lead to evidence based policy (Wellstead and Stedman, 2015). This report looks at the policy capacity initiatives included within frameworks created by United States and Canadian federal, provincial and state governments by using NVivo as a tool to conduct qualitative and quantitative analyses. The frameworks to be analyzed are from the water supply and demand, drought and flood planning, and forest and grassland ecosystems sectors. These specific sectors were chosen because they are especially vulnerable to the impacts of climate change, particularly in the Great Plains region of the US and Canada. This report will help identify which areas of policy capacity need to be addressed by these governments and in future frameworks and assessments. 


\subsection{Objectives of the Study}

This study will:

- Search for policy capacity initiatives within frameworks published by federal, state and provincial governments in the Unites States and Canada focusing on the water supply and demand; drought and flood planning; and forest and grassland ecosystems sectors

- Research the differences in representation of policy capacity initiatives between the United States and Canada

- Examine which of the initiatives are most represented and which need greater representation

- Investigate and discuss the driving factors behind the representation of these policy capacity initiatives

This report will first provide an outline of the previous literature relevant to the topic, followed by a detailed description of the methods used to obtain the data. The report will then present the findings and discuss the relevance of the findings, especially in the context of future policy implications. 


\section{CHAPTER TWO: LITERATURE REVIEW}

This report draws from several different knowledge areas within the social sciences; public policy, quantitative analysis; and content analysis. This literature review provides an introduction to the relevant topics and why they are pertinent to the goal of this paper and also their importance to better understand the direction in which Canadian and US environmental policy is progressing in terms of climate change adaptation policy.

\subsection{Climate Change Adaptation and Terminology}

To adequately understand climate change adaptation, it is important to understand the terminology behind the concept. Adaptation, vulnerability, adaptive capacity, and resilience are four terms used extensively in the relevant literature and within the adaptations and assessments.

Adaptive capacity is a term often encountered in the literature dealing with climate science and global climate change and has referred to a variety of different concepts. It has been used to refer to the practical adaptive capacity of countries to formulate public policy that would support this increase; as an organizing tool used by those who research the potential harm as a result of climate change and external stress; and in reference to the boundaries within which adaptation decisions are feasible (Burton, 1996; Yohe and Tol, 2002; Adger and Vincent, 2005). Researchers have stated that adaptive capacity is normally underestimated when considering climate change impacts resulting in a bottleneck for adaptation (Grothmann and Patt, 2005). This indicates that systems have a higher adaptive capacity than what we expected and thus greater levels of adaptation can be planned. Literature on adaptive capacity has focused on this 
phenomenon at varying scales, taking in to consideration specific countries, regions or issues (Brown et al. 2013; Engle and Johns, 2013; Endter-Wada et al. 2013).

Vulnerability can be described as the degree to which a system is susceptible to the greater variability brought about by global climate change and is often portrayed in a negative light (Adger, 2006). Vulnerability deals with the connections between human and natural systems and the dependence of humans on the natural (Adger, 2006). Discussion of vulnerability is often limited to certain areas or regions depending on both geographical factors as well as resource availability (Füssel, 2007). For a wider consideration of vulnerability it is essential to consider physical, economic, social, and environmental factors of the particular region being considered (Füssel, 2007). Vulnerability is often linked with resilience of a system, and sometimes even considered its antonym (Füssel, 2007). The term resilience was used in ecological literature long before it was incorporated into the climate change narrative (Holling, 1977). Even within the literature on climate change, resilience is often used in relation to ecological systems and their ability to withstand the varied impacts of climate change (Hughes et al., 2003).

Vulnerability, resilience and adaptive capacity are found to have a strong, but imprecise relationship (Gallopin, 2006). Research on climate change is that of open dynamic systems and their external environment and the three terms above all represent different manifestations of the response of systems to climate change (Gallopin, 2006). Adaptation to climate change in communities is a product of interactions of these three factors (Smit and Wandel, 2006).

In their 2000 paper, Smit et al. provide the background for climate change adaptation and its relation to variability. Their purpose is to provide a conceptual 
framework within which adaptation strategies can be applied and analyzed and to define the terminology prevalent in the field (Smit et al. 2000). Adaptations may be reactive or anticipatory; autonomous or planned; they may take on 'technological, economic, legal and institutional' forms (Smit et al. 2000). Smit et al. define adaptations as the 'adjustments in ecological-social-economic systems in response to actual or expected climatic stimuli' (2000).

Adaptation can take place at various scales, from that of a farmer's field to global systems and international food trade (Smit et al., 2000). At each of these levels, adaptation will take different paths and forms. There are some who believe that adaptation takes place on a smaller scale while mitigation has to take part on a global scale (Kruse and Putz, 2010). There is even an argument made for individual adaptation to climate change with personal decision making based on climate change and an analysis of the benefits and risks (Grothmann and Patt, 2005) These systems also have characteristics which impact their ability to adapt and are often referred to as the vulnerability, resilience or sensitivity of the system (Smit et al., 2000).There also exists maladaptation where a decrease in suitability may occur (Smit et al., 2000).

Additionally, climate change adaptation also has to deal with natural variability of the climate (Smit et al., 2000). Although adaptive responses may be autonomous or planned, policy regarding climate change is almost always planned while natural systems often undergo unplanned adaptation (Smit et al., 2000). Natural systems cannot anticipate the impacts of climate change like human systems can and so cannot prepare itself for the impacts. One such way in which unplanned adaptation happens is directly after an 
extreme event which opens the 'window of opportunity' for implementation of adaptation problems which had to that point only been discussed (Amundsen et al., 2010).

Moving forward in time, Smit and Wandel review adaptation concepts in relation to human systems and global changes in their 2006 paper. The authors define adaptation as the action through which a system becomes better able to cope with a changing condition (Smit and Wandel, 2006). The authors assert that although there are several variations to this description used in literature, all of the definitions follow this basic theme (Smit and Wandel, 2006). The authors discuss how the concepts of adaptation, adaptive capacity, vulnerability, resilience, exposure and sensitivity at different scales and to different forces are related to each other in terms of global climate change (Smit and Wandel, 2006). In contrast to Smit et al.'s paper published in 2000, this paper reviews the terms as they have been applied within the different fields of natural sciences, social sciences and anthropology. The authors assert that the adaptations have been analyzed with different end points in mind.

The first form of analyses used is to estimate the ability of the adaptations to mitigate the impacts of climate change; the second is more focused on the efficacy of particular adaptations for specific systems, the third focuses on the vulnerability or adaptive capacity of the particular regions being analyzed and the fourth deals with the practical side of the adaptation initiatives (Smit and Wandel, 2006). In theory, all adaptations are supposed to mitigate the impacts of climate change. Tying these approaches together, the authors state that "Adaptations are manifestations of adaptive capacity and they represent ways of reducing vulnerability (Smit and Wandel, 2006 pp 286)." Thus a system with greater adaptive capacity to climate change will be less 
vulnerable (Smit and Wandel, 2006). However, it is important to remember that there is a fluctuating 'coping range' of adaptive capacity beyond which the vulnerability of the system will increase once more (Smit and Wandel, 2006). Of the analyses discussed in this paper, that of practical applications of adaptation initiatives is the most pertinent in terms of mainstreaming and the integration of these concepts into pre-existing and emerging policies.

According to the latest report by the IPCC, the need for climate change adaptation will increase in the future with greater expected variability in climate and significant changes across almost all biological and socio-ecological fields (IPCC, 2014). Although there may be some positive results of climate change, most impacts are expected to be negative (IPCC, 2014).

Tschakert and Dietrich refer to adaptation as a learning process and not a linear one as is described by a majority of researchers (2010). The authors assert that although a wealth of scientific information exists, this is often not available to a majority of policy makers creating a void and deterring the creation of capacity (Tschakert and Dietrich, 2010). The authors view adaptation as a "socioinstitutional process that involves cycles of anticipation and responses to a variety of stressors" and that it is "radically different from considering adaptation as an adjustment to predicted future climatic impacts or residual damage associated with these impacts" (Tschakert and Dietrich, 2010, pp 3-4). Thus the authors present adaptation as a more multifaceted and constantly evolving concept developed through experimentation compared to just a simple response to socioeconomical vulnerabilities (Tschakert and Dietrich, 2010). 
When considering climate change, it is important to understand and acknowledge that there are limits to the extent to which a society can adapt. Adger et al. (2009) discuss the social limits and the factors behind them. They underscore the fact that those living through the 21st century will experience constantly changing climates and that society will have to adapt on ecological, physical, economic and technical levels (Adger et al., 2009). Understanding the social limits allows a better understanding of how to create more effective climate change policy and assists in providing a concrete framework for analysis and formulation (Adger et al., 2009). The authors provide four domains- ethics, knowledge, risk, and culture, which make up the social limits and go on to discuss how these limits interact with the physical world and deduce whether they actually present a challenge for climate change adaptation (Adger et al., 2009). The authors concluded that

the main limitations to climate change adaptation were the values, perceptions, processes and power structures of the society in question(Adger et al., 2009). This paper by Adger et al. emphasizes the importance of analyzing the processes and power structures in the society. This report will attempt to do so by content analysis of frameworks which have been created by the governmental entities and power structures in this situation. Analysis of these frameworks will provide insight in to the limits created within the societies in question.

\subsection{Climate Change Adaptation Frameworks}

Climate change adaptation frameworks provide an example of governmental agencies creating a document to act as a guide for users who are seeking to prepare for climate change and its eventualities (Burton et al, 2005). The guides exist as a way for the 
users to consider both present and future realities and priorities when choosing on which adaptation measures to adopt (Burton et al,. 2005). An adaptation framework should be useful across different scales and appealing to a wide range of stakeholders (Burton et al,. 2005). This means that the framework should be easily accessible and not overburdened with either scientific or policy technical terms.

Fussel and Klein outline the methods in which evaluation of climate change vulnerabilities have changed over time to demonstrate the various approaches which have been used and to facilitate interdisciplinary collaboration (2007). The authors emphasize the need for both adaptation and mitigation and consideration of these in aid budgets to countries which are especially vulnerable because both information and resources are essential to climate change adaptation (Fussel and Klein, 2007). The authors present three models for conceptualizing and assessing vulnerability; the risk-hazard framework; the social constructivist framework and the human geography causal structure (Fussel and Klein, 2007). These look at different dimensions of vulnerability, with the risk-hazard framework focusing on the technical side and the other two forms focused on social vulnerability (Fussel and Klein, 2007). The overall trends observed by the authors were that the assessments were becoming increasingly interdisciplinary and complex and implementation concerns were starting to be considered (Fussel and Klein, 2007).

There have been evaluations of climate change assessment plans, especially concentrating on European Union countries. Massey presents his research as a comparison and categorizing tool rather than a ranking one (Massey, 2010). The factors which he focuses on are adaptation level, adaptation objective, and adaptation aim (Massey, 2010). These terms refer to how far along a country is in the process, why they 
are addressing the specific issue, and what exactly the country is doing to address it. The author addresses the adaptation strategies and how far along the definition and implementation stages are; he analyses the purpose behind the adaptation measures; and reviews the domains and socioeconomic sectors which will be impacted by these policies (Massey, 2010). The purpose of the paper was to provide a snapshot of where EU countries stand in terms of adaptation policy and the changes in the past five years and not as an in depth analysis of the policies themselves (Massey, 2010).

Comparisons of adaptation strategies were also undertaken by Biesbroek et al. focusing on European Union countries with high adaptive capacity (2010). Biesbroek et al. examined National Adaptation Strategies (NAS), impact and vulnerability assessments, national communication reports and communication strategies (2010). Biesbroek et al.'s paper provides insight into what factors are relevant in facilitating adaptation policy and how research has been progressing over time (2010). Six themes were chosen for analysis: "1) the motivation behind establishing of NASs; 2) the interaction between science-policy and research co-ordination 3) approaches for communication and knowledge transfer; 4) the ways in which tasks and responsibilities are distributed between different levels of governance; 5) the institutional arrangements for incorporating adaptation into sectoral policies; and 6) whether and how countries ensure that their adaptation strategies are implemented and reviewed" (Biesbroek, 2010; pp 442). The authors concluded that multilevel governance and policy integration was essential to maximize the impact of adaptation policies due to their interdependent nature (Biesbroek, 2010). 


\subsection{Climate Change Adaptation and Policy}

The challenges posed in the creation of international mitigation policy has led to many governments creating adaptation plans focused on smaller national and provincial or state sectors (Wellstead et al., 2013). However, these plans present numerous initiatives and suggestions without taking in to consideration the policy processes which would be required (Wellstead et al., 2013). The authors analyze vulnerability assessments from three different countries and conclude that in all three cases, governance is considered merely as an input variable in calculating adaptive capacity and not given sufficient consideration (Wellstead et al., 2013). This lack of consideration for policy processes in these vulnerability assessments are expected to lead to unintended outcomes and policy failures (Wellstead et al., 2013). The authors state that the discussion of governance within these existing polices "have been pitched at too high a level of abstraction" and that the assessments don't identify the policy issues which would prevent policy implementation (Wellstead et al., 2013 pp9). This paper by Wellstead et al. indicates that the lack of consideration of governance and policy is universal within vulnerability assessments and adaptation plans, especially in the first generation of these documents. This report will look in to the level at which the governance, and other policy issues and capacities are considered within the climate change adaptation plans in question.

When discussing climate change adaptation and the translation to policy it is essential to know whether policy is actually supporting adaptation or taking away from it. This is precisely what Urwin and Jordan discuss in their 2007 paper. Urwin and Jordan discuss the need to integrate climate change and related policies related to all aspects of 
old and new policy (2007). Additionally, they suggest that limiting factors such as scientific uncertainty, technology, and financial resources need to be discussed within the policy framework (Urwin and Jordan, 2007). Urwin and Jordan focus on the concept of policy interplay and how older policies tend not to support climate adaptation objectives (Urwin and Jordan, 2007). The authors also discuss the issues brought forward due to the conflict between top down and bottom up policy making and the various horizontal and vertical dimensions which mask the actual interplays which are taking place. Suggestions offered in the paper to improve climate change policy include more localized processes to prevent antagonistic policies because policies planned at a larger scale can have unforeseen localized impacts (Urwin and Jordan, 2007). It is essential to view these policies as cross cutting issues rather than solely environmental ones (Urwin and Jordan, 2007). The authors do bring forward the proposition of climate proofing all existing policies, but deemed it to be too difficult a task and one which is unlikely to have a wide ranging impact (Urwin and Jordan, 2007). One major reason why climate proofing is difficult is due to the fact that most sectors have short term budgetary plans and constraints making it difficult to consider a far reaching concept such as climate change. Another point brought forward by the authors is that what is happening at the street level is often very different from what was dictated by policy makers and the best way forward would be to reconcile the obvious conflicts rather than overhauling all policy (Urwin and Jordan, 2007). 


\subsection{Different Types of Policy Capacity}

Policies related to climate change adaptation are based on scientific information, that is, climate change adaptation policy is largely evidence based. The ability of the policy makers to analyze and incorporate this information is essential, and this is discussed in Howlett's 2009 paper. Here, Howlett discusses the need for informed empirical analysis and its usefulness in helping governments improve, especially since systemic review does not exist in many of these policy areas (2009). Howlett stresses that policy makers must have the analytical capability to collect and analyze these large volumes of information involved in the implementation of evidence based policies (Howlett, 2009). Howlett's work is particularly relevant since he is writing about the Canadian government and the challenges faced in the adoption of evidence based techniques and many of the frameworks discussed in this paper are from Canadian sectors.

However, policy analytical capacity is not the only type of capacity which would help these governments create the framework required to adequately adapt to climate change. Figure 1 below, from Wu et al.(2015), outlines the nine typologies of policy capacity, which allows for the distinction between the levels and dimensions of policy capacity. The policy capacity terms are presented in a matrix form to make it simpler to examine the different levels and dimensions.

The climate change adaptation frameworks will be analyzed to ascertain whether these nine types of policy capacity are addressed by government agencies. The authors state that previous definitions and descriptions of policy capacity were inadequate and thus they attempt to comprehensively discuss and define the nine types of policy capacity 
(Wu et al., 2015). While some scholars define policy capacity as solely existing in the public sphere, others have a more holistic view that includes other resources which are available (Wu et al., 2015). The authors state that there is a gap in the literature due to the fact that most of the existing literature focuses on one particular dimension and that it is their intention to fill this gap with the framework below (Wu et al., 2015). The authors address all levels of policy capacity that would be needed for successful analyses, formulation, implementation and evaluation of policy (Wu et al., 2015). The authors emphasize the need for there to be a certain trust in the government for the political aims of the framework to be fulfilled (Wu et al., 2015). The framework also acts as a tool to better understand existing literature and also inform policy makers as to which capacities need to be improved and how (Wu et al., 2015). From a climate change adaptation perspective, knowledge system capacity could look be the open availability and sharing of climate data between educational institutes and policy makers. One example would be the NOAA drought monitor based at the University of Nebraska, Lincoln. This monitor provides country wide drought and precipitation predictions and past data available to everyone and easily accessible when required for policy decisions (United States Drought Monitor). Another example from the climate change arena is the Environmental Protection Agency's (EPA) climate change program. This program seeks to provide data, evaluate policy options and cost, and partner internationally and locally to create analytical, managerial and political capacity at various levels (EPA). 


\begin{tabular}{|c|c|c|c|}
\hline $\begin{array}{l}\text { Level } \\
\text { Dimension }\end{array}$ & INDIVIDUAL & $\begin{array}{l}\text { ORGANIZATIONA } \\
\mathrm{L}\end{array}$ & SYSTEMIC \\
\hline Analytical & $\begin{array}{l}\text { Analytical Capacity } \\
\text { Knowledge of policy } \\
\text { substance and } \\
\text { analytical techniques } \\
\text { and communication } \\
\text { skills }\end{array}$ & $\begin{array}{l}\text { Technical Capacity } \\
\text { Capability in data } \\
\text { collection; } \\
\text { Availability of } \\
\text { software and } \\
\text { hardware for analysis } \\
\text { and evaluation; } \\
\text { Storage and } \\
\text { Dissemination of } \\
\text { operational } \\
\text { information (eg. } \\
\text { client need, service } \\
\text { utilization; budget, } \\
\text { human resources.); E- } \\
\text { services. }\end{array}$ & $\begin{array}{l}\text { Knowledge System } \\
\text { Capacity } \\
\text { Availability and } \\
\text { sharing of data for } \\
\text { policy research and } \\
\text { analysis; availability, } \\
\text { quality and the level of } \\
\text { competition of policy } \\
\text { advisory services in } \\
\text { and out of government; } \\
\text { presence of high } \\
\text { quality educational and } \\
\text { training institutions } \\
\text { and opportunities for } \\
\text { knowledge generation, } \\
\text { mobilization and use } \\
\text { access to information }\end{array}$ \\
\hline Managerial & $\begin{array}{l}\text { Managerial } \\
\text { Capacity } \\
\text { strategic } \\
\text { management, } \\
\text { leadership, } \\
\text { communication, } \\
\text { negotiation and } \\
\text { conflict resolution, } \\
\text { financial } \\
\text { management and } \\
\text { budgeting }\end{array}$ & $\begin{array}{l}\text { Administrative Cap } \\
\text { acity } \\
\text { Funding, staffing, } \\
\text { levels of Intra- and } \\
\text { inter-agency } \\
\text { communication, } \\
\text { consultation, and } \\
\text { coordination. }\end{array}$ & $\begin{array}{l}\text { Governance Capacity } \\
\text { Levels of Inter- } \\
\text { organizational trust } \\
\text { and communication; } \\
\text { Adequate fiscal system } \\
\text { to fund programs and } \\
\text { projects; }\end{array}$ \\
\hline Political & $\begin{array}{l}\text { Political Acumen } \\
\text { Capacity } \\
\text { Understanding of the } \\
\text { needs and positions } \\
\text { of different } \\
\text { stakeholders; } \\
\text { judgment of political } \\
\text { feasibility; } \\
\text { Communication } \\
\text { skills }\end{array}$ & $\begin{array}{l}\text { Political Resource } \\
\text { Capacity } \\
\text { Access to key policy- } \\
\text { makers; Effective } \\
\text { Civil Service bargain. } \\
\text { Politicians' support } \\
\text { for the agency } \\
\text { programmes and } \\
\text { projects. }\end{array}$ & $\begin{array}{l}\text { Legitimation } \\
\text { Capacity } \\
\text { Level of public } \\
\text { participation in policy } \\
\text { process; } \\
\text { Public Trust; Presenc } \\
\text { e of rule of law and } \\
\text { transparent } \\
\text { adjudicative system }\end{array}$ \\
\hline
\end{tabular}

Source: Modeled after Wu et al 2010 and Tiernan and Wanna 2006

Figure 1: A framework of policy capacity typologies 


\subsection{The use of Nvivo in Qualitative research in the social sciences}

Qualitative research differs from quantitative research in that social structures and processes can be examined and also because unexpected information can be unearthed (Wong, 2008). Previously, qualitative data analysis used to be very labor intensive and involved a multitude of paper and notecards (Wong 2008). Using computer software to identify and code the data has made this process more efficient even though the main synthesis, interpretation, and coding still has to be carried out by the researcher (Wong

2008). However, once the coding is done, the resulting qualitative data can be modeled to examine the relationships between different subjects of the research (Wong 2008). 


\section{CHAPTER THREE: DATA AND METHODS}

This report relies heavily on content analysis. In 1989 Krippendorff referred to content analysis as one of the most important research techniques in the social sciences which analyzes the data taking in to consideration the context in which the data was created. Content analysis can be attributed to both public and private communications in various written, verbal and visual forms (Krippendorff 1989). Content analysis has the added benefit that data for favored hypotheses are not selected for by the researcher and that all data receives equal consideration. The steps in content analysis can be described using Figure 2. 


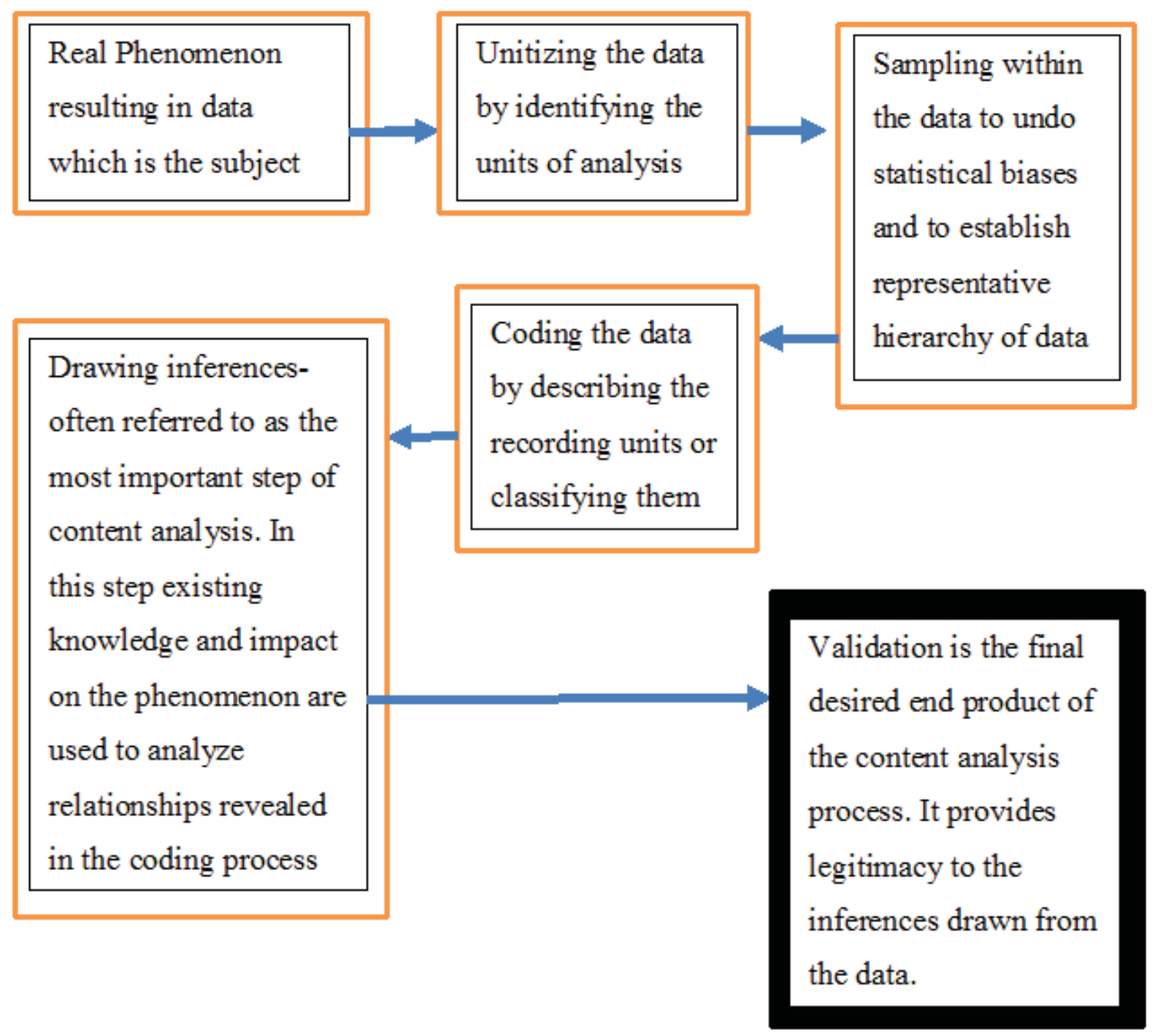

Figure 2: The process of content analysis adapted from Krippendorff 1989

Content analysis can be used in different social sciences fields by virtue of its flexibility and the fact that it can be used for a wide range of qualitative analysis depending on the needs of the researcher (Hsieh and Shannon, 2005). Hsieh and Shannon divide content analysis into three different categories based on study design and analytical procedures (2005). They define qualitative content analysis as "a research method for the subjective 
interpretation of the content of text data through the systematic classification process of coding and identifying themes or patterns" (Hsieh and Shannon, 2005, pp 1278).

The first category, 'Conventional Content Analysis' is associated with a study design used to describe a phenomenon and descriptive data categories which arise from the data itself (Hsieh and Shannon, 2005). If interviews are conducted, questions are open ended and later coded and organized in clusters based on the descriptive data collected and often the clusters themselves are analyzed for connections (Hsieh and Shannon, 2005). Challenges of this method of analysis include the fact that key categories are often unidentified and the fact that this approach itself can be confused with other qualitative methods resulting in this method yielding content which is mostly concept development and model building (Hsieh and Shannon, 2005). The second category used by Hsieh and Shannon is 'Directed Content Analysis' and is often used in conjunction with existing theories and frameworks and is more structured than the conventional content analysis (2005). In this situation, coding and clusters are pre-selected and targeted questions are asked in interviews. Detractors of this method point to the fact that dependence on existing theories often leads to a failure in recognizing contextual situations (Hsieh and Shannon, 2005). The third category described by Hsieh and Shannon is 'Summative Content Analysis' and focuses on identifying and understanding contextual use of content and quantifying usage (Hsieh and Shannon, 2005). This method of content analysis has been used to analyze manuscript types or textbook content and is considered a nonreactive way of carrying out research (Hsieh and Shannon, 2005). The authors underscore the importance of accurate coding in all three types of analysis (Hsieh and Shannon, 2005). 
Content analysis may be carried out using an inductive or deductive method as described by Elo and Kyngas (2008). The authors describe content analysis as a method of analyzing different modes of communication messages and a "systemic and objective means of describing and quantifying phenomena" (Elo and Kyngas, 2008, p108). Classification or coding allows for the data to be condensed in to fewer categories and carrying out content analysis allows us to identify processes and divide them according to meanings and context (Elo and Kyngas, 2008). The purpose of the study determines whether content analysis is used in a deductive or inductive method: the inductive approach is used in studies where not much previous background exists whereas the deductive method is used on the basis of previous knowledge and the aim is to test the theories being examined (Elo and Kyngas, 2008).

Regardless of approach used, both types of processes have three main phases involving the preparation, organization and reporting of the data (Elo and Kyngas, 2008). In the preparation phase it must be ensured that the sample is representative of what is being studied and the unit of analysis must be chosen with care to ensure that it is neither too broad nor too narrow (Elo and Kyngas, 2008). In the inductive content analysis method coding is often done while the researcher is immersed in it, while in the deductive method a matrix is first established and data assigned to it as the data is reviewed (Elo and Kyngas, 2008). The authors also mention that care must be taken so that the results are described in a way which is clear to those who are reading the research (Elo and Kyngas, 2008). While carrying out coding and categorizing, it is important to keep in mind that content analysis is not a linear process, nor is there an existing rigid structure. 
The analysis will vary depending on the issue being processed, and that is what makes this process challenging (Elo and Kyngas, 2008).

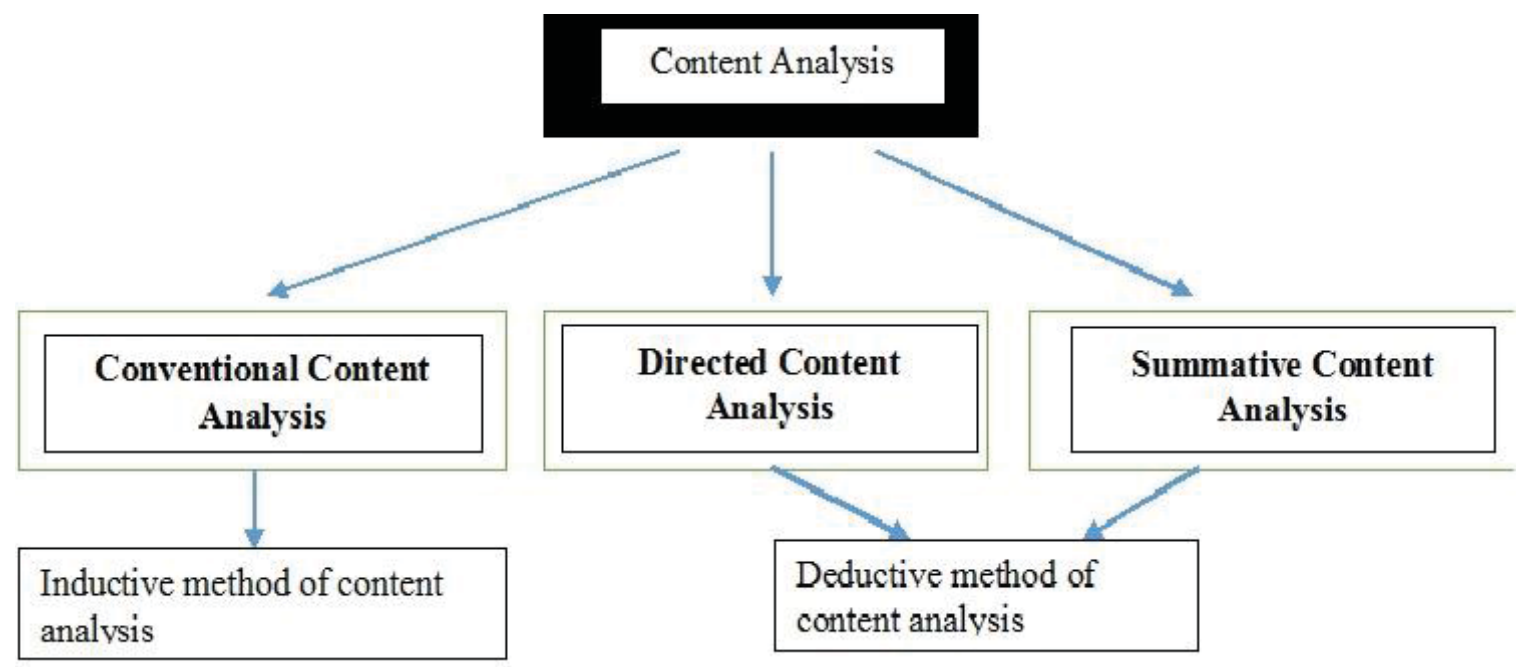

Figure 3: The three types of content analysis and the method of content analysis used. Using information from Elo and Kyngas, 2008, and Hsieh and Shannon, 2005.

\subsection{Collection and Inclusion/Exclusion Criteria}

The data used for this report are Climate Change Adaptation Frameworks which were published by the federal, provincial and state governments of the United States and Canada. They were collected by searching departmental websites during the summer of 2014. The Canadian frameworks used can be found in Appendix A and the American frameworks in Appendix B. Initially, a total of 218 frameworks were collected from both countries. The frameworks are divided in to the primary sectors which they address; water supply and demand; drought and flood planning; and forest and grassland 
ecosystems. Frameworks which were not classified under the three categories as a primary sector were excluded from the analysis.

\subsection{Coding of the Data}

The data in the form of the framework pdfs were uploaded in to NVivo, which is a Computer Assisted Qualitative Data Analysis Software (CAQDAS). The text search query 'capacity' was applied to the data. The results of the search were then coded according to which of the above policy capacity terms in Figure 1 they represent. If they fail to represent any one of the terms, that particular 'capacity' result is excluded from the analysis. The nine policy capacity terms are used as nodes for further analysis of the data. Screenshots of the NVivo windows are provided in Appendix C. The process is outlined in Table 1.

Table 1: Steps in NVivo content analysis

\begin{tabular}{|l|l|}
\hline Steps in Content Analysis & Description \\
\hline Step 1: Framework upload & $\begin{array}{l}\text { All relevant frameworks are uploaded in } \\
\text { to NVivo in the form of pdfs }\end{array}$ \\
\hline Step 2: Node Creation within NVivo & $\begin{array}{l}\text { Nodes are created for the nine policy } \\
\text { capacities }\end{array}$ \\
\hline Step 3: Text Search & $\begin{array}{l}\text { A query for 'capacity' is carried out } \\
\text { within the relevant frameworks }\end{array}$ \\
\hline Step 4: Coding & $\begin{array}{l}\text { All incidences of 'capacity' in the } \\
\text { frameworks are analyzed and coded } \\
\text { according to policy capacity node. Some } \\
\text { incidences may not refer to any form of } \\
\text { policy capacity while others may code for } \\
\text { more than one. }\end{array}$ \\
\hline
\end{tabular}




\subsection{Challenges in Coding}

There were a number of challenges coding data because many of the mentions of ‘capacity' within the frameworks referred to more than one kind of policy capacity. However, an overwhelming number of mentions also did not refer to any form of policy capacity at all. Parsing through and analyzing this data required a high level of critical thinking and close reading. Some incidences of the word 'capacity' referred to more than one type of policy capacity and care had to be taken to not code the data towards a node which it did not represent. However, in other instances the frameworks were intentionally vague so as to refer to several different forms of policy capacity. References to capacity using other words is beyond the scope of this study.

\subsection{Analyzing the Results}

To explore the data, both NVivo and Microsoft Excel were used. Data was input into excel from NVivo raw data. This allowed for greater visualization of the data across various platforms and diagrams. In some instances Excel allowed for greater comparison of the data as can be seen within the pie charts in the results section. Within NVivo, analysis was mostly in relation of one node to the others and therefore limited in scope. General qualitative trends in the data were noted and quantitative information was analyzed. Differences between Canadian and US representation and representation of the three different sectors were also analyzed. The relationships between the different types of policy capacity were illustrated using a NVivo cluster diagram as in Figure 10. 


\section{CHAPTER FOUR: RESULTS}

\subsection{General Trends in Data}

Of the 210 United States and Canadian Frameworks, only 84 were used in this study as they were classified as having one of the three sectors examined in this report as the primary sector. All 84 frameworks and assessments used are listed in Appendix A and Appendix B. A simple search for the word 'capacity' resulted in 54 frameworks with 655 instances of the word within the text. Analyzing these instances of the word capacity and assigning them to a specific type or types of capacity gives us the number of frameworks which address each type of policy capacity and the combined number of instances they were mentioned as illustrated in Table 2. It was found that only 30 of the frameworks used the word 'capacity' in reference to policy capacity. Additionally, any one instance of the word capacity was often used to refer to more than one type of policy capacity. In one US federal framework, one mention of capacity encompassed all nine types of policy capacity being examined in this report. Table 2 demonstrates that Technical capacity was the most discussed initiative whereas political resource capacity and legitimation capacity are the least discussed initiatives. 
Table 2: Types of policy capacity and references within the frameworks

\begin{tabular}{|l|l|l|}
\hline Type of Policy Capacity & Number of frameworks & Number of instances \\
\hline Technical Capacity & 13 & 28 \\
\hline Managerial Capacity & 12 & 26 \\
\hline Administrative Capacity & 10 & 21 \\
\hline $\begin{array}{l}\text { Knowledge System } \\
\text { Capacity }\end{array}$ & 12 & 17 \\
\hline $\begin{array}{l}\text { Governance Capacity } \\
\text { Political Acumen Capacity }\end{array}$ & 13 & 16 \\
\hline Analytical Capacity & 5 & 13 \\
\hline Political Resource Capacity & 1 & 1 \\
\hline Legitimation Capacity & 1 & 1 \\
\hline
\end{tabular}

During coding of the data, it was also observed that most of the time that capacity was used in the text, it was used in reference to biological or natural resource capacities. Even when policy capacity was discussed, it was often a brief mention and not an in depth description of how exactly policy capacity would be increased. This sentence used in a US federal summary of U.S. Agency Missions and Capabilities in Water: "Capacity building in scientific, technical, financial, operations and management, policy, and legal aspects of water resources management;" mentions all nine forms of capacity, albeit briefly and was coded as such. It is the only source which even remotely mentions political resource capacity and legitimation capacity. Further examples of the different policy capacity types can be found in Table 3. 
Table 3: Policy capacity examples from Canadian and US frameworks

\begin{tabular}{|l|l|}
\hline Policy capacity type & Example and Source Framework \\
\hline Analytical Capacity & $\begin{array}{l}\text { "The desired outcome is increased capacity to apply } \\
\text { climate change information, knowledge and tools in BC } \\
\text { forest management" Source: British Columbia Forest } \\
\text { Stewardship Action Plan for Climate Change Adaptation }\end{array}$ \\
\hline "The majority of respondents supported FFEI as timely \\
and important; however, some were skeptical its purpose \\
could be achieved with limited government capacity to \\
carry out the necessary research, forecasting, monitoring, \\
and policy evaluation" Source: Strategic Plan of the \\
Future Forests Ecosystem Initiative
\end{tabular}




\begin{tabular}{|c|c|}
\hline & $\begin{array}{l}\text { frameworks, and financial resources" Source: New York } \\
\text { State Sea Level Rise Task Force framework }\end{array}$ \\
\hline \multirow[t]{2}{*}{ Administrative Capacity } & $\begin{array}{l}\text { "They also provide policy advice, capacity building, and } \\
\text { sector analysis to help strengthen the operational and } \\
\text { financial sustainability of water systems globally" } \\
\text { Source: US federal summary of U.S. Agency Missions } \\
\text { and Capabilities in Water }\end{array}$ \\
\hline & $\begin{array}{l}\text { "BC forest managers have the knowledge, tools and } \\
\text { organizational capacity to adapt BC forest practices for a } \\
\text { changing climate" Source: British Columbia Forest } \\
\text { Stewardship Action Plan for Climate Change Adaptation. }\end{array}$ \\
\hline \multirow[t]{2}{*}{ Governance Capacity } & $\begin{array}{l}\text { "The fixed location of tribal lands defines important } \\
\text { limits, however, to the adaptive capacity of tribal } \\
\text { communities with regard to climate change" Source: US } \\
\text { forest sector framework on the Effects of Climatic } \\
\text { Variability and Change on Forest Ecosystems }\end{array}$ \\
\hline & $\begin{array}{l}\text { Discussion of support and capacity development as } \\
\text { features of effective engagement Source: Natural } \\
\text { Resource Canada presentation focused on coastal climate } \\
\text { change adaptation challenges in maritime provinces }\end{array}$ \\
\hline \multirow[t]{2}{*}{ Political Acumen Capacity } & $\begin{array}{l}\text { "Participatory processes represent a collective learning } \\
\text { approach, to build consensus, foster local empowerment, } \\
\text { and increase community capacity" Source: Scenarios for } \\
\text { vulnerability Assessment by the Canadian Council of } \\
\text { Forest Ministers }\end{array}$ \\
\hline & $\begin{array}{l}\text { "Mechanisms such as grant programs, technical } \\
\text { assistance programs, legal training and capacity building } \\
\text { to encourage and support vulnerability assessments, } \\
\text { implementing coastal resilience plans and post-planning } \\
\text { implementation activities available to both government } \\
\text { planners and community representatives" Source: New } \\
\text { York State Sea Level Rise Task Force framework }\end{array}$ \\
\hline Political resource Capacity & $\begin{array}{l}\text { "Capacity building in scientific, technical, financial, } \\
\text { operations and management, policy, and legal aspects of } \\
\text { water resources management;" Source: US federal } \\
\text { summary of U.S. Agency Missions and Capabilities in } \\
\text { Water }\end{array}$ \\
\hline Legitimation Capacity & $\begin{array}{l}\text { "Capacity building in scientific, technical, financial, } \\
\text { operations and management, policy, and legal aspects of } \\
\text { water resources management;" Source: US federal } \\
\text { summary of U.S. Agency Missions and Capabilities in } \\
\text { Water }\end{array}$ \\
\hline
\end{tabular}


Figure 4 also illustrates the occurrence of these initiatives in the literature with the area of each of the boxes representing the number of times that each type of policy capacity was referred too.

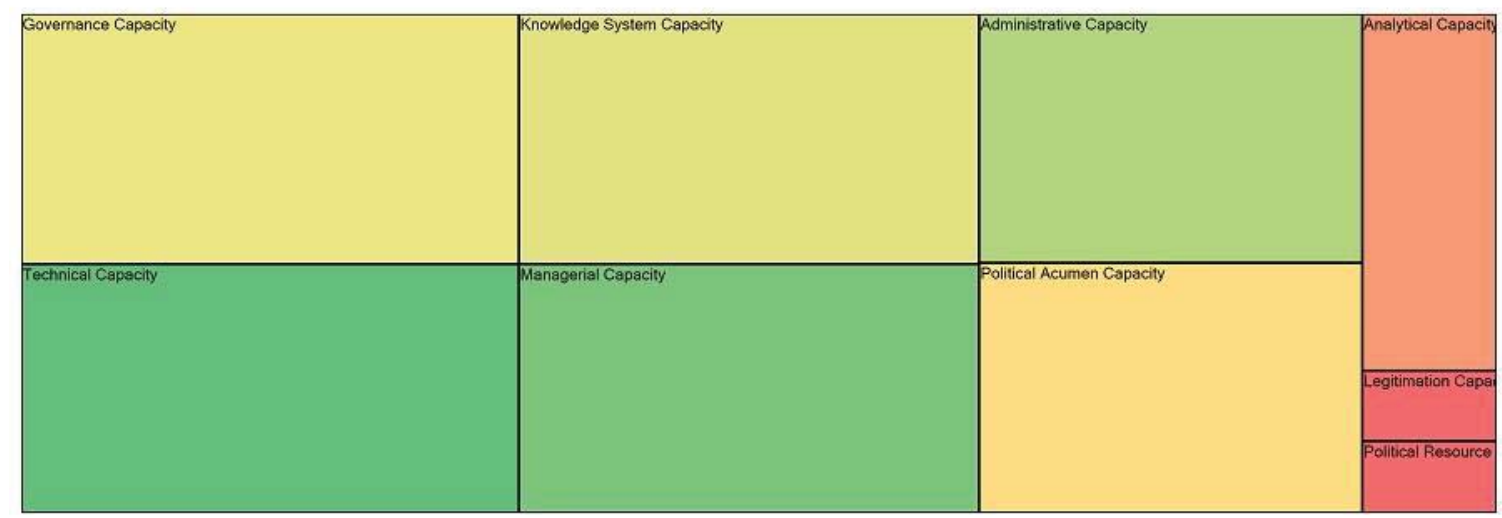

Figure 4: Tree diagram created within NVivo representing frequency of occurrence of policy capacity initiatives in literature

\subsection{Comparing US and Canadian Data}

The 84 frameworks on which the first step of the search was carried out was comprised of 45\% US frameworks and assessments and 55\% Canadian frameworks. There were more Canadian documents available as compared to US documents. The origins of the documents were different as well. In the US, $86 \%$ of these assessments and frameworks are from federal sources while in Canada only 30\% are from federal sources and the rest are from various provinces and territories. 


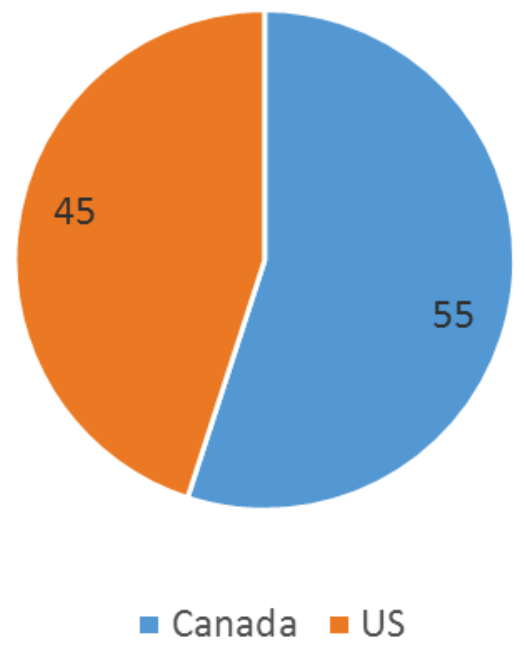

Figure 5: Representation by country of the 84 frameworks on which the first step of the search was done
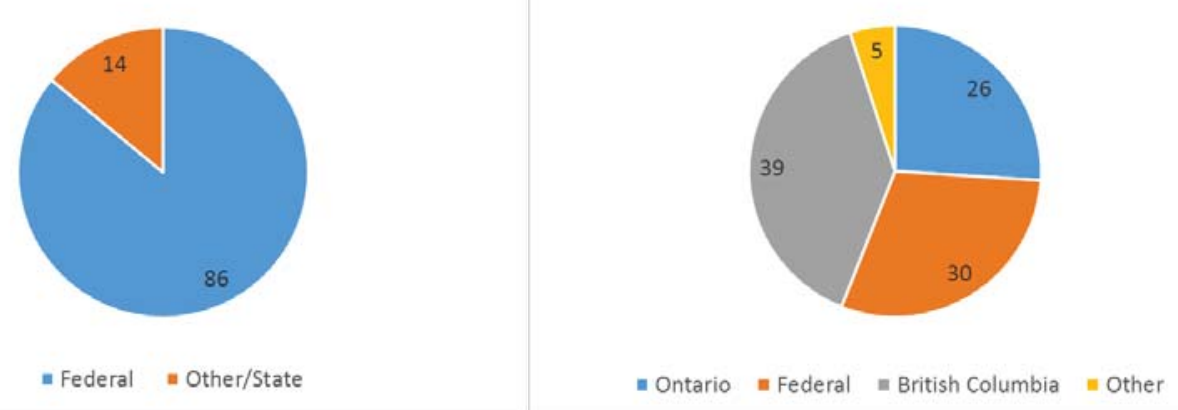

Figure 6: Pie charts illustrating the source of the 84 frameworks from the three different sectors in the US and Canada 
After coding for policy capacity, it was found that $67 \%$ of the frameworks which mentioned policy capacity initiatives were Canadian and 33\% were from the US (Figure 7) . Again, Canada is better represented than the US.

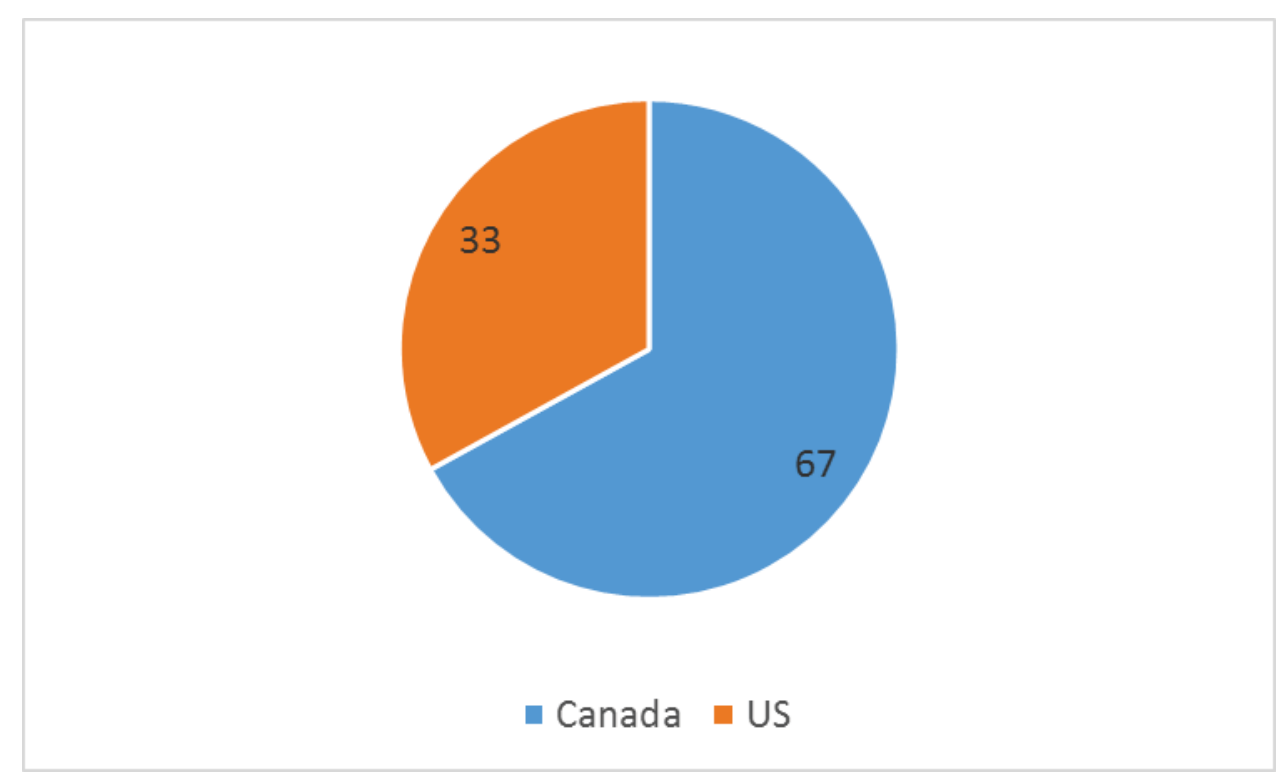

\section{Figure 7: Country distribution of frameworks and assessments which refer to policy capacity}

However, if we were to take a look at the number of times policy capacity initiatives were mentioned within the frameworks, we see that the US governmental units have been more diligent at referencing policy capacity than Canadian governmental units. The US has almost double the number of references to policy capacity even though they comprise of only half of the frameworks which contain references to policy capacity (Figure 8). 


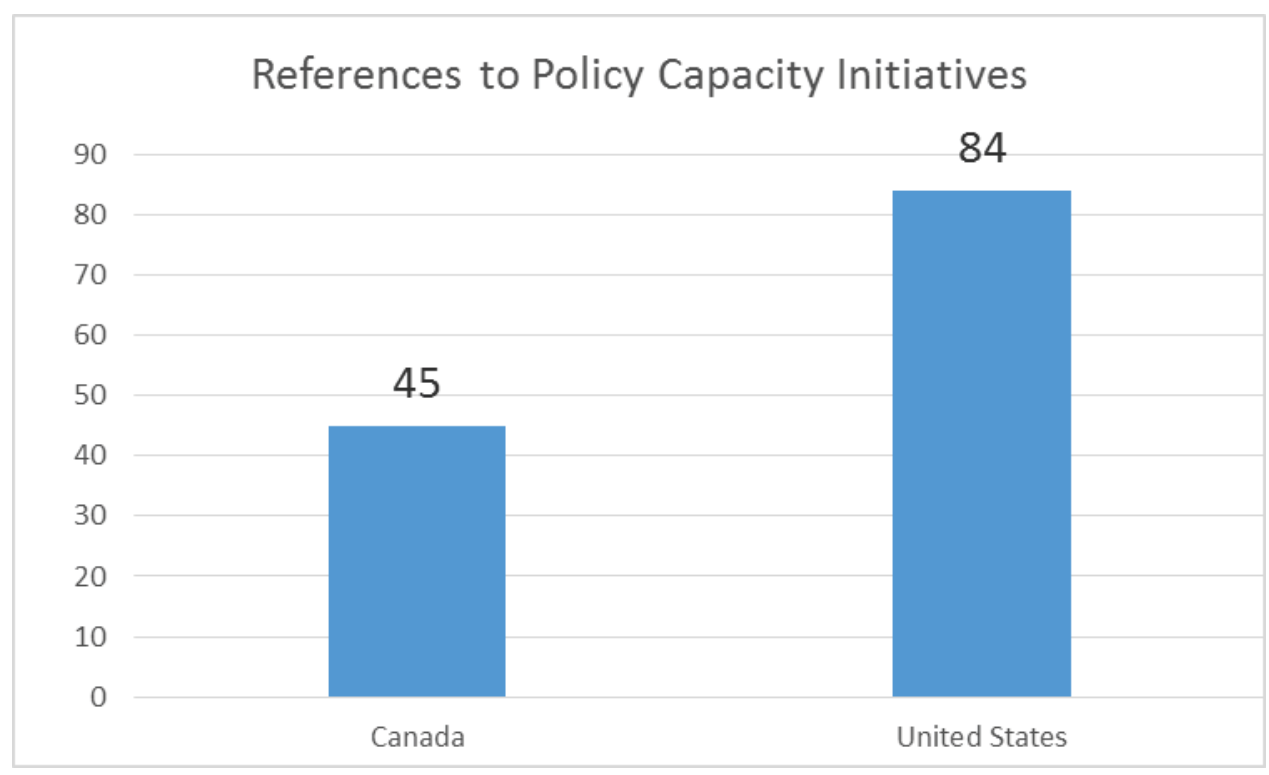

Figure 8: Number of references to policy capacity initiatives in the US and Canada

\subsection{Sectors Represented by Frameworks Which Mention Policy Capacity}

Figure 9 illustrates the distribution of the three sectors which are being considered in this report and contain reference to at least one form of policy capacity. Of the total assessments and frameworks which refer to policy capacity, over 50\% are from the Forest and Grassland ecosystem sector, followed by $27 \%$ from the water supply and demand sector and only $20 \%$ from the drought and flood planning sector. 


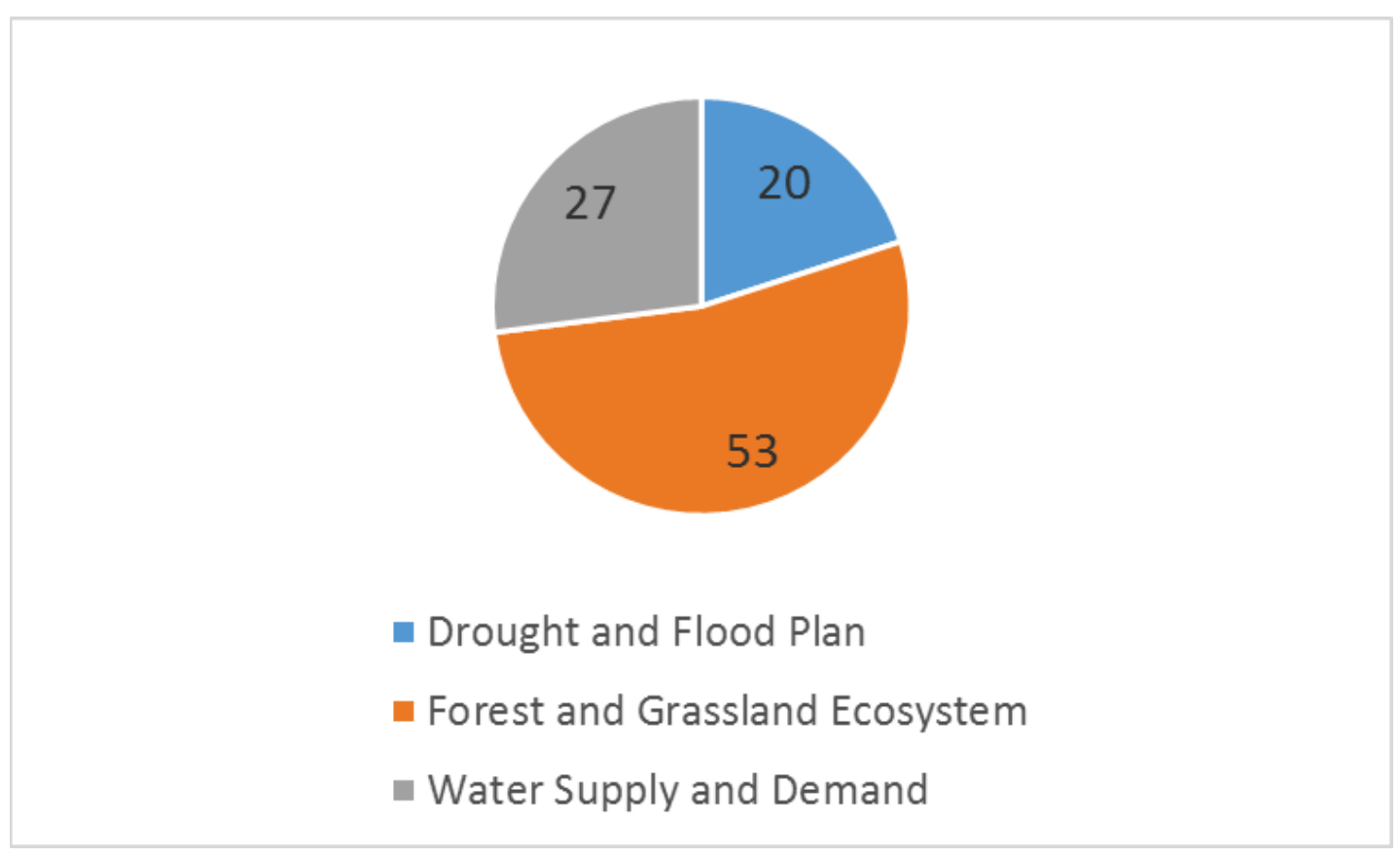

Figure 9: Distribution of sectors based on mention of policy capacity

\subsection{Relationships within the Different Types of Policy Capacity}

Analytical capacity, legitimation capacity and political resource capacity are the least discussed types of policy capacity (Figure 10) and this is corroborated by Table 2 and Figure 4. Figure 10 also indicates that these three are discussed within the same frameworks. Knowledge system capacity and technical capacity too were discussed in the same frameworks.

Figure 10 represents the frequency of occurrence in the literature and clearly demonstrates that knowledge system and technical capacity are much more widely discussed than any other type of policy capacity whereas legitimation capacity and political resource capacity are described only briefly. Figure 10 demonstrates that frameworks discussing analytical capacity, legitimation capacity and political resource capacity also discussed the other forms of capacity. However the other forms of capacity 
were also mentioned in frameworks which did not discuss these three types of frameworks.

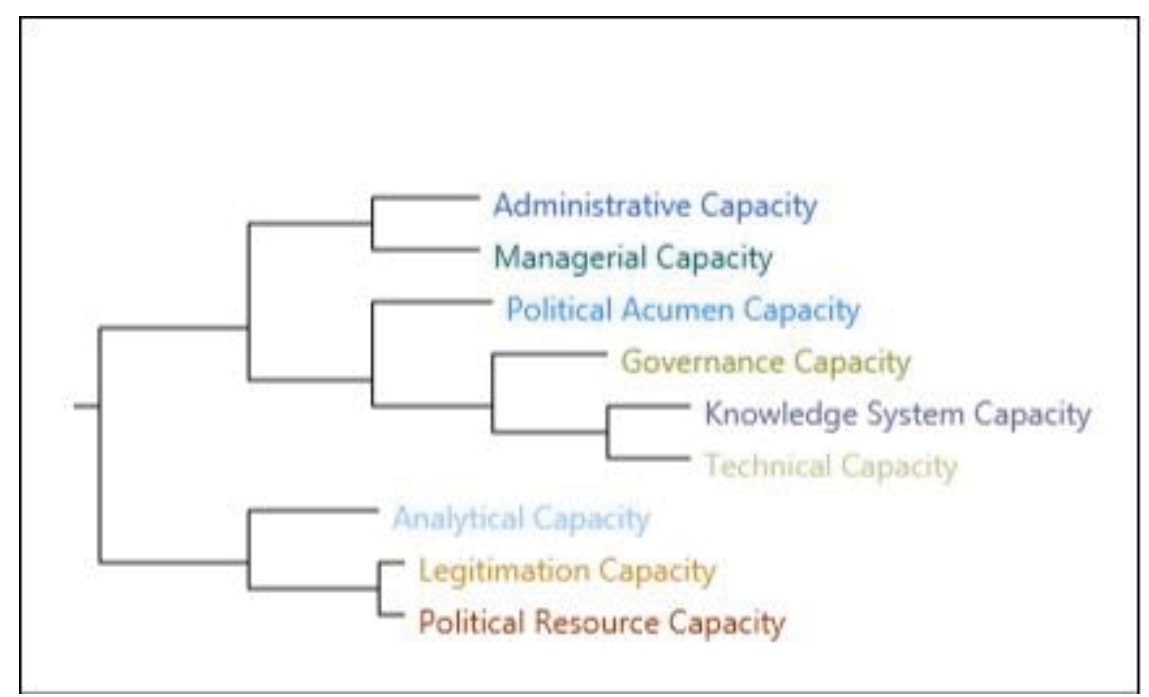

Figure 10: Cluster Diagram of Policy Capacity Types to exhibit relationship between them 


\section{CHAPTER FIVE: DISCUSSION}

Of the 84 climate change adaptation frameworks and assessments examined, only 54 contained any mention of the word 'capacity' and of those 54, a mere 30 were referring to policy capacity. This lack of policy capacity initiatives within the public policy sphere are well documented, especially in terms of policy analytical capacity, and are found to be especially pronounced within the environmental policy sector (Jänicke, 1997; Lemos and Agarwal, 2006). Although significant work has been done concerning policy analytical capacity, this report focuses on all forms of policy capacity as defined by Wu et al. in their 2015 paper thus making it difficult to compare to previous instances of policy capacity metrics. However, older sources report a lack of policy analytical capacity and integrative governance, two factors which were taken in to consideration when constructing the policy capacity matrix in Figure 1 (Craft and Howlett, 2012; Wu et al. 2015).

Technical capacity is the type of policy capacity which is most widely referred to within the frameworks. It refers primarily to the technical aspect of data collection and dissemination. Technical capacity is one aspect of climate change adaptation which has been supported since the very beginning of the discussion with IPCC frameworks focusing on the science and data of climate change. Thus it can be concluded that governmental organizations have been developing this particular capacity for decades at this point and have the existing resources to further develop this capacity. Additionally, educational institutions are also involved in data collection and dissemination, further 
increasing the resources available for this particular type of capacity to continue growing in influence.

Following technical capacity, the managerial dimension was most widely included within the adaptation frameworks, followed by analytical and political capacity. This pattern may be expected because most of the documents are meant for people who are working on managing these natural resource fields - making these more of a focus than other fields. One unexpected result was the relative absence of analytical capacity. This lack may be explained by the fact that these frameworks are not targeted towards those policy workers who are interpreting and applying policy. Rather, in this context working with set guidelines may be more important than analyzing the policy. Also, many of these frameworks were dealing with general capacity building which happens more with the other types of capacity in question than solely analytical capacity.

The political dimension is not discussed much at all within the frameworks. Only political acumen capacity is widely discussed while political resource capacity and legitimation capacity are referred to only once and within the same framework. High levels of political acumen capacity can be linked to a growing movement of including local stakeholders in environmental decisions made regarding their local landscapes (Buysse and Verbeke, 2003; Gregory and Wellman, 2001). However, without sufficient levels of other forms of political capacity, many decisions made will not be able to be translated in to functioning public policy. This may also have been done purposefully to eliminate the political factor of these reports and concentrate on the technical and managerial sides. 
While the US and Canadian governments have both invested in creating frameworks, the overall number of Canadian frameworks is larger than the number created by the US governments. Additionally, there is a greater percentage of federal frameworks in the US while Canada has frameworks from a wide variety of provinces in addition to the federal frameworks. This disparity can have significant impacts when considering the scale at which climate adaptation is going to take place. The Canadian frameworks focus on a smaller scale and often within limited areas. The US frameworks on the other hand mostly refer to the entire US, or larger geographical territories. This generalized approach can be an advantage considering the fact that climate change and it impacts are not limited to a certain area. On the other hand, the specialized frameworks seen in Canada allow for greater levels of analysis and collaboration regarding specific issues or natural areas.

Although Canada has a greater number of frameworks in the analysis, these frameworks contain fewer references to policy capacity. Thus the effectiveness of these frameworks may be questioned. Is it better to have fewer frameworks which address a wider range of policy issues or a larger number of frameworks which refer to smaller range of policy capacities?

The number of frameworks from each of the three sectors is also unequal, with forest and grassland ecosystems having the greatest number of frameworks in the analysis. This is an indication that the leaders in the drought and flood planning, and water supply and demand sectors also need to step up and create frameworks where necessary. 
The data also reveals that some frameworks are much more inclusive to types of policy capacity than others. In particular, some of the US federal frameworks which are summaries created by the government organization try to touch upon all of the types of policy capacity, however briefly.

The main challenge in this study was the coding for the various capacity types as operationalizing these terms is subjective. This is an area that future studies could work on. The other challenge is the fact that not all frameworks may have been collected in the initial data search. Additionally, new frameworks and assessments may have been released after that search. These more recent frameworks may include more references to policy capacity as governments work to make the environmental policy process more efficient and effective. Further studies could also focus on more in depth analysis of the frameworks and discussions of the similarities and dissimilarities between them. 


\section{CHAPTER SIX: POLICY IMPLICATIONS}

The research done in this report indicates that work needs to be done to improve the political dimension of policy capacity, especially political resource capacity and legitimation capacity. These two types of policy capacity are often not discussed at all within the frameworks except in a very general sense. Without consideration of these aspects, no real change can happen because policy cannot be formulated, much less implemented. Additionally, there needs to be more discussion of all aspects of policy capacity in the data. There is a lot of discussion of the scientific basis, but not what can be done with it. Which is why policy capacity is of such importance. Going forward, climate change adaptations frameworks and assessments need to include all aspects of policy capacity.

Another interesting point revealed is that although Canada has many more frameworks, the US ones actually include more references to policy capacity. Thus it is a reminder that quantity does not equal quality when discussing these frameworks. The same principal can also be applied to the sectoral frameworks- some sectors have many more frameworks than others, but are they all addressing important and diverging concepts, or are they merely copies of one central framework? A lot of effort is put in to creating these frameworks, and it is essential that they are useful to the individuals who have to use them. 


\section{References}

Adger, W. N. (2006). Vulnerability. Global environmental change, 16(3), 268-281.

Adger, W. N. (2010). Social capital, collective action, and adaptation to climate change. In Der klimawandel (pp. 327-345). VS Verlag für Sozialwissenschaften

Adger, W. N., \& Vincent, K. (2005). Uncertainty in adaptive capacity. Comptes Rendus Geoscience, 337(4), 399-410.

Amundsen, H., Berglund, F., \& Westskog, H. (2010). Overcoming barriers to climate change adaptation - a question of multilevel governance?. Environment and Planning $C$ Government and Policy, (28), 276-289.

Biesbroek, G. R., Swart, R. J., Carter, T. R., Cowan, C., Henrichs, T., Mela, H., ... \& Rey, D. (2010). Europe adapts to climate change: comparing national adaptation strategies. Global environmental change, 20(3), 440-450.

Burton, I., \& Development Programme United Nations. (2005). Adaptation policy frameworks for climate change: developing strategies, policies and measures(p. 258). B. Lim (Ed.). Cambridge: Cambridge University Press.

Brown, H., Smit, B., Somorin, O. A., Sonwa, D. J., \& Ngana, F. (2013).

Institutional perceptions, adaptive capacity and climate change response in a post-conflict country: a case study from Central African Republic.Climate and Development, 5(3), 206-216

Burton, I. (1996). The growth of adaptation capacity: practice and policy. Adapting to Climate Change (pp. 55-67). Springer New York. 
Buysse, K., \& Verbeke, A. (2003). Proactive environmental strategies: a stakeholder management perspective. Strategic management journal, 24(5), 453-470.

Craft, J., \& Howlett, M. (2012). Subsystem structures, shifting mandates and policy capacity: Assessing Canada's ability to adapt to climate change. Canadian Political Science Review, 6(1), 3-14.

Elo, S., \& Kyngäs, H. (2008). The qualitative content analysis process. Journal of advanced nursing, 62(1), 107-115.

EPA (What EPA is Doing)

http://www.epa.gov/climatechange/EPAactivities.html

Essential Background (Essential Background)

http://unfccc.int/essential_background/items/6031.php

Embrett, M.G., Randall, G.E., Social Determinants of Health and Health Equity Policy Research: Exploring the Use, Misuse, and Nonuse of Policy Analysis Theory, Social Science \& Medicine (2014)

Endter-Wada, J., Welsh, L., Downard, R., \& Kettenring, K. (2013). Developing Adaptive Capacity to Droughts: The Rationality of Locality. Ecology and Society, 8(2), Article-7.

Engle, N. L., \& Johns, O. (2013). Building Adaptive Capacity to Climate Change in Less Developed Countries. Climate Science for Serving Society: Research, Modeling and Prediction Priorities, 437.

Füssel, H. M. (2007). Vulnerability: a generally applicable conceptual framework for climate change research. Global environmental change, 17(2), 155-167. 
Füssel, H. M., \& Klein, R. J. (2006). Climate change vulnerability assessments: an evolution of conceptual thinking. Climatic change, 75(3), 301-329.

Gallopín, G. C. (2006). Linkages between vulnerability, resilience, and adaptive capacity. Global environmental change, 16(3), 293-303.

Gregory, R., \& Wellman, K. (2001). Bringing stakeholder values into environmental policy choices: a community-based estuary case study.Ecological Economics, 39(1), 3752.

Grothmann, T., \& Patt, A. (2005). Adaptive capacity and human cognition: the process of individual adaptation to climate change. Global Environmental Change, 15(3), 199-213.

Holling, C. S. (1973). Resilience and stability of ecological systems. Annual review of ecology and systematics, 1-23.

Hsieh, H. F., \& Shannon, S. E. (2005). Three approaches to qualitative content analysis. Qualitative health research, 15(9), 1277-1288.

Hughes, T. P., Baird, A. H., Bellwood, D. R., Card, M., Connolly, S. R., Folke, C., ... \& Roughgarden, J. (2003). Climate change, human impacts, and the resilience of coral reefs. science, 301(5635), 929-933.

Jänicke, M. (1997). The political system's capacity for environmental policy. InNational environmental policies (pp. 1-24). Springer Berlin Heidelberg.

Kruse, S., Pütz, M., \& Sozialwissenschaften, F. P. U. (2010). Climate change adaptation.

IPCC (Intergovernmental Panel on Climate Change). 2014. "Summary for Policymakers." In Climate Change 2014. Impacts, Adaptation, and Vulnerability. Part A: 
Global and Sectoral Aspects. Contribution of Working Group II to the Fifth Assessment Report of the Intergovernmental Panel on Climate Change, edited by C. B. Field, V. R. Barros, D. J. Dokken, K. J. Mach, M. D. Mastrandrea,T. E. Bilir, M. Chatterjee, K. L. Ebi, Y. O. Estrada, R. C. Genova, B. Girma, E. S. Kissel, A. N. Levy, S. MacCracken, P. R. Mastrandrea, and L. L.White, 1-32. Cambridge and New York: Cambridge University Press.

Krippendorff, K. (1989). Content analysis. In E. Barnouw, G. Gerbner, W. Schramm, T. L. Worth, \& L. Gross (Eds.), International encyclopedia of communication (Vol. 1, pp. 403-407). New York, NY: Oxford University Press.

Kyoto Protocol (Kyoto Protocol)

http://unfccc.int/kyoto_protocol/items/2830.php

Lemos, M. C., \& Agrawal, A. (2006). Environmental governance. Annu. Rev. Environ. Resour., 31, 297-325.

Lobell, D. B., Burke, M. B., Tebaldi, C., Mastrandrea, M. D., Falcon, W. P., \& Naylor, R. L. (2008). Prioritizing climate change adaptation needs for food security in 2030. Science, 319(5863), 607-610.

Massey, E. (2010) Report: Assessing Adaptation in the EU an Update. Adaptation to the changing climate: time to intensify efforts.

Olmos, S. (2001). Vulnerability and adaptation to climate change: concepts, issues, assessment methods. Climate Change Knowledge Network Foundation Paper, Oslo.

Scott, D., McBoyle, G., \& Mills, B. (2003). Climate change and the skiing industry in southern Ontario (Canada): exploring the importance of snowmaking as a technical adaptation. Climate research, 23(2), 171-181. 
Smit, B., Burton, I., Klein, R. J., \& Wandel, J. (2000). An anatomy of adaptation to climate change and variability. Climatic change, 45(1), 223-251.

Smit, B., \& Wandel, J. (2006). Adaptation, adaptive capacity and vulnerability. Global environmental change, 16(3), 282-292.

Tiernan, A., \& Wanna, J. (2006, November). Competence, capacity, capability: towards conceptual clarity in the discourse of declining policy skills. In Govnet International Conference, Australian National University. Canberra.

Tschakert, P., \& Dietrich, K. A. (2010). Anticipatory learning for climate change adaptation and resilience. Ecology and society, 15(2), 11.

United States Drought Monitor > Home (United States Drought Monitor > Home) http://droughtmonitor.unl.edu/

Urwin, K., \& Jordan, A. (2008). Does public policy support or undermine climate change adaptation? Exploring policy interplay across different scales of governance. Global environmental change, 18(1), 180-191.

Wellstead, A. M., Howlett, M., \& Rayner, J. (2013). The neglect of governance in forest sector vulnerability assessments: Structural-functionalism and "black box" problems in climate change adaptation planning. Ecology and Society,18(3), 23.

Wellstead, A. \& Stedman, R. (2015) Mainstreaming and Beyond: Policy Capacity and Climate Change Decision-Making. Michigan Journal of Sustainability. Manuscript Accepted 
Wong, L. (2008). Data Analysis in Qualitative Research: A Brief Guide to Using Nvivo. Malaysian Family Physician: The Official Journal of the Academy of Family Physicians of Malaysia, 3(1), 14-20.

Wu, Xun, M. Ramesh, Michael Howlett, and Scott Fritzen. The Public Policy Primer: Managing Public Policy. London: Routledge, 2010.

Wu, Xun, M. Ramesh, Michael Howlett. (2015) Blending Skill and Resources Across Multiple Levels of Activity: Competences, Capabilities and the Policy Capacities of Government. Prepared for the Special Issue of Policy \& Society on Policy Capacity

Yohe, G., \& Tol, R. S. (2002). Indicators for social and economic coping capacitymoving toward a working definition of adaptive capacity. Global Environmental Change, 12(1), 25-40. 
Appendix A: Canadian Climate Change Assessments and Plans

\begin{tabular}{|c|c|c|c|}
\hline $\begin{array}{l}\text { Province/Federal } \\
\text { Government }\end{array}$ & $\begin{array}{l}\text { Department/Organizatio } \\
\mathrm{n}\end{array}$ & $\begin{array}{l}\text { Climate Change } \\
\text { Plan }\end{array}$ & Sector \\
\hline Alberta & $\begin{array}{l}\text { Climate Change } \\
\text { Landscape Projection } \\
\text { Group }\end{array}$ & $\begin{array}{l}\text { Impacts of Climate } \\
\text { Change at the Stand } \\
\text { Level }\end{array}$ & $\begin{array}{l}\text { Forest and } \\
\text { Grassland } \\
\text { Ecosystem }\end{array}$ \\
\hline British Columbia & $\begin{array}{l}\text { Climate Action } \\
\text { Initiative }\end{array}$ & $\begin{array}{l}\text { BC Farm Practices } \\
\text { and Climate Change } \\
\text { Adaptation- } \\
\text { Drainage }\end{array}$ & $\begin{array}{l}\text { Drought and } \\
\text { Flood Planning }\end{array}$ \\
\hline British Columbia & $\begin{array}{l}\text { Climate Action } \\
\text { Initiative }\end{array}$ & $\begin{array}{l}\text { BC Farm Practices } \\
\text { and Climate Change } \\
\text { Adaptation- Delta }\end{array}$ & $\begin{array}{l}\text { Drought and } \\
\text { Flood Planning }\end{array}$ \\
\hline British Columbia & $\begin{array}{l}\text { Climate Action } \\
\text { Initiative }\end{array}$ & $\begin{array}{l}\text { BC Farm Practices } \\
\text { and Climate } \\
\text { Change- Peace } \\
\text { Region }\end{array}$ & $\begin{array}{l}\text { Drought and } \\
\text { Flood Planning }\end{array}$ \\
\hline British Columbia & $\begin{array}{l}\text { British Columbia } \\
\text { Ministry of } \\
\text { Environment }\end{array}$ & $\begin{array}{l}\text { Sea Level Rise } \\
\text { Adaptation Primer }\end{array}$ & $\begin{array}{l}\text { Drought and } \\
\text { Flood Planning }\end{array}$ \\
\hline British Columbia & $\begin{array}{l}\text { British Columbia } \\
\text { Ministry of Forests and } \\
\text { Range }\end{array}$ & $\begin{array}{l}\text { Adapting to Climate } \\
\text { Change in Forest } \\
\text { Management-A } \\
\text { Management } \\
\text { Agency Response }\end{array}$ & $\begin{array}{l}\text { Forest and } \\
\text { Grassland } \\
\text { Ecosystem }\end{array}$ \\
\hline British Columbia & $\begin{array}{l}\text { British Columbia } \\
\text { Ministry of Forests and } \\
\text { Range }\end{array}$ & $\begin{array}{l}\text { Integrating climate } \\
\text { change adaptation } \\
\text { into forest } \\
\text { management }\end{array}$ & $\begin{array}{l}\text { Forest and } \\
\text { Grassland } \\
\text { Ecosystem }\end{array}$ \\
\hline British Columbia & $\begin{array}{l}\text { British Columbia } \\
\text { Ministry of Forests and } \\
\text { Range }\end{array}$ & $\begin{array}{l}\text { Responding to } \\
\text { Climate Change: } \\
\text { Assisting seedlot } \\
\text { migration to } \\
\text { maximize } \\
\text { adaptation of future } \\
\text { forest plantations }\end{array}$ & $\begin{array}{l}\text { Forest and } \\
\text { Grassland } \\
\text { Ecosystem }\end{array}$ \\
\hline British Columbia & $\begin{array}{l}\text { British Columbia } \\
\text { Ministry of Forests and } \\
\text { Range }\end{array}$ & $\begin{array}{l}\text { Adaptation } \\
\text { Strategies }\end{array}$ & $\begin{array}{l}\text { Forest and } \\
\text { Grassland } \\
\text { Ecosystem }\end{array}$ \\
\hline British Columbia & $\begin{array}{l}\text { British Columbia } \\
\text { Ministry of Forests and } \\
\text { Range }\end{array}$ & $\begin{array}{l}\text { Adapting Tree } \\
\text { Species Selection } \\
\text { for a Changing } \\
\text { Climate }\end{array}$ & $\begin{array}{l}\text { Forest and } \\
\text { Grassland } \\
\text { Ecosystem }\end{array}$ \\
\hline
\end{tabular}




\begin{tabular}{|c|c|c|c|}
\hline British Columbia & $\begin{array}{l}\text { Ministry of Forests, } \\
\text { Lands and Natural } \\
\text { Resource Operations }\end{array}$ & $\begin{array}{l}\text { Climate Change } \\
\text { Strategy (2013 - } \\
\text { 2018) }\end{array}$ & $\begin{array}{l}\text { Forest and } \\
\text { Grassland } \\
\text { Ecosystem }\end{array}$ \\
\hline British Columbia & $\begin{array}{l}\text { Ministry of Forests, } \\
\text { Lands and Natural } \\
\text { Resource Operations }\end{array}$ & $\begin{array}{l}\text { A Climate Change } \\
\text { Vulnerability } \\
\text { Assessment for } \\
\text { B.C.'s Managed } \\
\text { Forests }\end{array}$ & $\begin{array}{l}\text { Forest and } \\
\text { Grassland } \\
\text { Ecosystem }\end{array}$ \\
\hline British Columbia & $\begin{array}{l}\text { Ministry of Forests and } \\
\text { Range Forest Science } \\
\text { Program }\end{array}$ & $\begin{array}{l}\text { Climate Change, } \\
\text { Impacts, and } \\
\text { Adaptation } \\
\text { Scenarios: Climate } \\
\text { Change and Forest } \\
\text { and Range } \\
\text { Management in } \\
\text { British Columbia }\end{array}$ & $\begin{array}{l}\text { Forest and } \\
\text { Grassland } \\
\text { Ecosystem }\end{array}$ \\
\hline British Columbia & $\begin{array}{l}\text { Ministry of Forests, } \\
\text { Lands and Natural } \\
\text { Resource Operations }\end{array}$ & $\begin{array}{l}\text { Forest Stewardship } \\
\text { Action Plan for } \\
\text { Climate Change } \\
\text { Adaptation }\end{array}$ & $\begin{array}{l}\text { Forest and } \\
\text { Grassland } \\
\text { Ecosystem }\end{array}$ \\
\hline British Columbia & $\begin{array}{l}\text { Ministry of Forests, } \\
\text { Lands and Natural } \\
\text { Resource Operations }\end{array}$ & $\begin{array}{l}\text { Climate Change } \\
\text { Adaptation: } \\
\text { Potential } \\
\text { Contributions of } \\
\text { Red Alder in } \\
\text { Coastal British } \\
\text { Columbia }\end{array}$ & $\begin{array}{l}\text { Forest and } \\
\text { Grassland } \\
\text { Ecosystem }\end{array}$ \\
\hline British Columbia & $\begin{array}{l}\text { Ministry of Forests and } \\
\text { Range }\end{array}$ & $\begin{array}{l}\text { Future Forest } \\
\text { Ecosystems } \\
\text { Initiative }\end{array}$ & $\begin{array}{l}\text { Forest and } \\
\text { Grassland } \\
\text { Ecosystem }\end{array}$ \\
\hline British Columbia & $\begin{array}{l}\text { MINISTRY OF } \\
\text { FORESTS AND } \\
\text { RANGE }\end{array}$ & $\begin{array}{l}\text { Future Forest } \\
\text { Ecosystems of BC }\end{array}$ & $\begin{array}{l}\text { Forest and } \\
\text { Grassland } \\
\text { Ecosystem }\end{array}$ \\
\hline British Columbia & Forest Services & $\begin{array}{l}\text { Biogeoclimatic } \\
\text { Ecosystem } \\
\text { Classification and } \\
\text { Climate Change }\end{array}$ & $\begin{array}{l}\text { Forest and } \\
\text { Grassland } \\
\text { Ecosystem }\end{array}$ \\
\hline British Columbia & $\begin{array}{l}\text { Climate Action } \\
\text { Initiative }\end{array}$ & $\begin{array}{l}\text { BC Farm Practices } \\
\text { and Climate Change } \\
\text { Adaptation- Water } \\
\text { Storage }\end{array}$ & $\begin{array}{l}\text { Water Supply } \\
\text { and Demand }\end{array}$ \\
\hline $\begin{array}{l}\text { Federal } \\
\text { Government }\end{array}$ & Environment Canada & $\begin{array}{l}\text { Threats to Water } \\
\text { Availability in } \\
\text { Canada- Droughts }\end{array}$ & $\begin{array}{l}\text { Drought and } \\
\text { Flood Planning }\end{array}$ \\
\hline
\end{tabular}




\begin{tabular}{|c|c|c|c|}
\hline $\begin{array}{l}\text { Federal } \\
\text { Government }\end{array}$ & Environment Canada & $\begin{array}{l}\text { Threats to Water } \\
\text { Availability in } \\
\text { Canada- Flood }\end{array}$ & $\begin{array}{l}\text { Drought and } \\
\text { Flood Planning }\end{array}$ \\
\hline $\begin{array}{l}\text { Federal } \\
\text { Government }\end{array}$ & $\begin{array}{l}\text { Natural Resources } \\
\text { Canada }\end{array}$ & $\begin{array}{l}\text { Coastal Climate- } \\
\text { Change Adaptation } \\
\text { Challenges in the } \\
\text { Maritime Provinces }\end{array}$ & $\begin{array}{l}\text { Drought and } \\
\text { Flood Planning }\end{array}$ \\
\hline $\begin{array}{l}\text { Federal } \\
\text { Government }\end{array}$ & $\begin{array}{l}\text { Atlantic Climate } \\
\text { Adaptation Solutions } \\
\text { Association }\end{array}$ & $\begin{array}{l}\text { Flood Risk and } \\
\text { Vulnerability } \\
\text { Analysis Project }\end{array}$ & $\begin{array}{l}\text { Drought and } \\
\text { Flood Planning }\end{array}$ \\
\hline $\begin{array}{l}\text { Federal } \\
\text { Government }\end{array}$ & $\begin{array}{l}\text { Canadian Council of } \\
\text { Forest Ministers }\end{array}$ & $\begin{array}{l}\text { Adapting } \\
\text { Sustainable Forest } \\
\text { Management to } \\
\text { Climate Change: } \\
\text { An Overview of } \\
\text { Approaches for } \\
\text { Assessing Human } \\
\text { Adaptive Capacity }\end{array}$ & $\begin{array}{l}\text { Forest and } \\
\text { Grassland } \\
\text { Ecosystem }\end{array}$ \\
\hline $\begin{array}{l}\text { Federal } \\
\text { Government }\end{array}$ & Environment Canada & $\begin{array}{l}\text { Threats to Water } \\
\text { Availability in } \\
\text { Canada- Forestry }\end{array}$ & $\begin{array}{l}\text { Forest and } \\
\text { Grassland } \\
\text { Ecosystem }\end{array}$ \\
\hline $\begin{array}{l}\text { Federal } \\
\text { Government }\end{array}$ & $\begin{array}{l}\text { Natural Resources } \\
\text { Canada }\end{array}$ & Adaptation & $\begin{array}{l}\text { Forest and } \\
\text { Grassland } \\
\text { Ecosystem }\end{array}$ \\
\hline $\begin{array}{l}\text { Federal } \\
\text { Government }\end{array}$ & $\begin{array}{l}\text { Canadian Council of } \\
\text { Forest Ministers }\end{array}$ & $\begin{array}{l}\text { VULNERABILITY } \\
\text { OF CANADA'S } \\
\text { TREE SPECIES } \\
\text { TO CLIMATE } \\
\text { CHANGE AND } \\
\text { MANAGEMENT } \\
\text { OPTIONS FOR } \\
\text { ADAPTATION }\end{array}$ & $\begin{array}{l}\text { Forest and } \\
\text { Grassland } \\
\text { Ecosystem }\end{array}$ \\
\hline $\begin{array}{l}\text { Federal } \\
\text { Government }\end{array}$ & $\begin{array}{l}\text { Canadian Council of } \\
\text { Forest Ministers }\end{array}$ & $\begin{array}{l}\text { Adapting } \\
\text { Sustainable Forest } \\
\text { Management to } \\
\text { Climate Change: A } \\
\text { Systematic } \\
\text { Approach for } \\
\text { Exploring } \\
\text { Organizational } \\
\text { Readiness }\end{array}$ & $\begin{array}{l}\text { Forest and } \\
\text { Grassland } \\
\text { Ecosystem }\end{array}$ \\
\hline $\begin{array}{l}\text { Federal } \\
\text { Government }\end{array}$ & $\begin{array}{l}\text { Canadian Council of } \\
\text { Forest Ministers }\end{array}$ & $\begin{array}{l}\text { Adapting } \\
\text { Sustainable Forest } \\
\text { Management to } \\
\text { Climate Change: }\end{array}$ & $\begin{array}{l}\text { Forest and } \\
\text { Grassland } \\
\text { Ecosystem }\end{array}$ \\
\hline
\end{tabular}




\begin{tabular}{|c|c|c|c|}
\hline & & $\begin{array}{l}\text { Preparing for the } \\
\text { Future }\end{array}$ & \\
\hline $\begin{array}{l}\text { Federal } \\
\text { Government }\end{array}$ & $\begin{array}{l}\text { Canadian Council of } \\
\text { Forest Ministers }\end{array}$ & $\begin{array}{l}\text { Adapting } \\
\text { Sustainable Forest } \\
\text { Management to } \\
\text { Climate Change: } \\
\text { Scenarios for } \\
\text { Vulnerability } \\
\text { Assessment } \\
\end{array}$ & $\begin{array}{l}\text { Forest and } \\
\text { Grassland } \\
\text { Ecosystem }\end{array}$ \\
\hline $\begin{array}{l}\text { Federal } \\
\text { Government }\end{array}$ & Environment Canada & $\begin{array}{l}\text { Threats to Water } \\
\text { Availability in } \\
\text { Canada- Freshwater } \\
\text { is a limited } \\
\text { Resource }\end{array}$ & $\begin{array}{l}\text { Water Supply } \\
\text { and Demand }\end{array}$ \\
\hline $\begin{array}{l}\text { Federal } \\
\text { Government }\end{array}$ & Environment Canada & $\begin{array}{l}\text { Canada's Oceans } \\
\text { Action Plan }\end{array}$ & $\begin{array}{l}\text { Water Supply } \\
\text { and Demand }\end{array}$ \\
\hline $\begin{array}{l}\text { Federal } \\
\text { Government }\end{array}$ & $\begin{array}{l}\text { Atlantic Climate } \\
\text { Adaptation Solutions } \\
\text { Association }\end{array}$ & $\begin{array}{l}\text { Climate Change } \\
\text { Adaptation } \\
\text { Groundwater } \\
\text { Management in } \\
\text { Atlantic Canada }\end{array}$ & $\begin{array}{l}\text { Water Supply } \\
\text { and Demand }\end{array}$ \\
\hline $\begin{array}{l}\text { Newfoundland } \\
\text { and Labrador }\end{array}$ & $\begin{array}{l}\text { Department of Natural } \\
\text { Resources }\end{array}$ & $\begin{array}{l}\text { COASTAL } \\
\text { MONITORING IN } \\
\text { NEWFOUNDLAN } \\
\text { D AND } \\
\text { LABRADOR }\end{array}$ & $\begin{array}{l}\text { Drought and } \\
\text { Flood Planning }\end{array}$ \\
\hline Ontario & $\begin{array}{l}\text { Grand River } \\
\text { Conservation Authority }\end{array}$ & $\begin{array}{l}\text { Making Watersheds } \\
\text { More Resilient to } \\
\text { Climate Change A } \\
\text { Response in the } \\
\text { Grand River } \\
\text { Watershed, Ontario } \\
\text { Canada: }\end{array}$ & $\begin{array}{l}\text { Drought and } \\
\text { Flood Planning }\end{array}$ \\
\hline Ontario & $\begin{array}{l}\text { Ministry of Natural } \\
\text { Resources }\end{array}$ & $\begin{array}{l}\text { An Evaluation of } \\
\text { Site Index Models } \\
\text { for Young Black } \\
\text { Spruce and Jack } \\
\text { Pine Plantations in a } \\
\text { Changing Climate }\end{array}$ & $\begin{array}{l}\text { Forest and } \\
\text { Grassland } \\
\text { Ecosystem }\end{array}$ \\
\hline Ontario & $\begin{array}{l}\text { Ministry of Natural } \\
\text { Resources }\end{array}$ & $\begin{array}{l}\text { Climate Change and } \\
\text { the Future Fire } \\
\text { Environment in } \\
\text { Ontario: Fire }\end{array}$ & $\begin{array}{l}\text { Forest and } \\
\text { Grassland } \\
\text { Ecosystem }\end{array}$ \\
\hline
\end{tabular}




\begin{tabular}{|c|c|c|c|}
\hline & & $\begin{array}{l}\text { Occurrence and Fire } \\
\text { Management } \\
\text { Impacts }\end{array}$ & \\
\hline Ontario & $\begin{array}{l}\text { Ministry of Natural } \\
\text { Resources }\end{array}$ & $\begin{array}{l}\text { Climate Change, } \\
\text { Carbon } \\
\text { Sequestration, and } \\
\text { Forest Fire } \\
\text { Protection in the } \\
\text { Canadian Boreal } \\
\text { Zone }\end{array}$ & $\begin{array}{l}\text { Forest and } \\
\text { Grassland } \\
\text { Ecosystem }\end{array}$ \\
\hline Ontario & $\begin{array}{l}\text { Ministry of Natural } \\
\text { Resources }\end{array}$ & $\begin{array}{l}\text { Forecasting the } \\
\text { Response to } \\
\text { Climate Change of } \\
\text { the Major Natural } \\
\text { Biotic Disturbance } \\
\text { Regime in Ontario's } \\
\text { Forests: the Spruce } \\
\text { Budworm }\end{array}$ & $\begin{array}{l}\text { Forest and } \\
\text { Grassland } \\
\text { Ecosystem }\end{array}$ \\
\hline Ontario & $\begin{array}{l}\text { Ministry of Natural } \\
\text { Resources }\end{array}$ & $\begin{array}{l}\text { Managing Tree } \\
\text { Seed in an } \\
\text { Uncertain Climate }\end{array}$ & $\begin{array}{l}\text { Forest and } \\
\text { Grassland } \\
\text { Ecosystem }\end{array}$ \\
\hline Ontario & $\begin{array}{l}\text { Ministry of Natural } \\
\text { Resources }\end{array}$ & $\begin{array}{l}\text { Assessing assisted } \\
\text { migration as a } \\
\text { climate change } \\
\text { adaptation strategy } \\
\text { for Ontario's forests }\end{array}$ & $\begin{array}{l}\text { Forest and } \\
\text { Grassland } \\
\text { Ecosystem }\end{array}$ \\
\hline Ontario & $\begin{array}{l}\text { Ministry of Natural } \\
\text { Resources }\end{array}$ & $\begin{array}{l}\text { Ontario's Forests } \\
\text { and Forestry in a } \\
\text { Changing Climate }\end{array}$ & $\begin{array}{l}\text { Forest and } \\
\text { Grassland } \\
\text { Ecosystem }\end{array}$ \\
\hline Ontario & $\begin{array}{l}\text { Ministry of Natural } \\
\text { Resources }\end{array}$ & $\begin{array}{l}\text { Guide for } \\
\text { Assessment of } \\
\text { Hydrologic Effects } \\
\text { of Climate Change } \\
\text { in Ontario }\end{array}$ & $\begin{array}{l}\text { Water Supply } \\
\text { and Demand }\end{array}$ \\
\hline Ontario & $\begin{array}{l}\text { Ministry of Natural } \\
\text { Resources }\end{array}$ & $\begin{array}{l}\text { Potential Changes } \\
\text { in Future Surface } \\
\text { Water Temperatures } \\
\text { in the Ontario Great } \\
\text { Lakes as a Result of } \\
\text { Climate Change }\end{array}$ & $\begin{array}{l}\text { Water Supply } \\
\text { and Demand }\end{array}$ \\
\hline Ontario & $\begin{array}{l}\text { Ministry of Natural } \\
\text { Resources }\end{array}$ & $\begin{array}{l}\text { Potential Effects of } \\
\text { Climate Change and } \\
\text { Adaptive Strategies } \\
\text { for Lake Simcoe } \\
\text { and the Wetlands }\end{array}$ & $\begin{array}{l}\text { Water Supply } \\
\text { and Demand }\end{array}$ \\
\hline
\end{tabular}




\begin{tabular}{|c|c|c|c|}
\hline & & $\begin{array}{l}\text { and Streams Within } \\
\text { the Watershed }\end{array}$ & \\
\hline Ontario & $\begin{array}{l}\text { Ministry of Natural } \\
\text { Resources }\end{array}$ & $\begin{array}{l}\text { Regional } \\
\text { Projections of } \\
\text { Climate Change } \\
\text { Effects on Ice } \\
\text { Cover and Open- } \\
\text { Water Duration for } \\
\text { Ontario Lakes }\end{array}$ & $\begin{array}{l}\text { Water Supply } \\
\text { and Demand }\end{array}$ \\
\hline
\end{tabular}


Appendix B: United States Climate Change Assessments and Plans

\begin{tabular}{|c|c|c|c|}
\hline $\begin{array}{l}\text { State/Federal } \\
\text { Government }\end{array}$ & $\begin{array}{l}\text { Department/Organizatio } \\
\mathrm{n}\end{array}$ & Climate Change Plan & Sector \\
\hline Arizona & University publication & $\begin{array}{l}\text { Climate Change } \\
\text { Adaptation Lessons } \\
\text { from the Land of } \\
\text { Dry Heat }\end{array}$ & $\begin{array}{l}\text { Water Supply } \\
\text { and Demand }\end{array}$ \\
\hline California & County of Imperial & $\begin{array}{l}\text { Water Supply } \\
\text { Assessment }\end{array}$ & $\begin{array}{l}\text { Water Supply } \\
\text { and Demand }\end{array}$ \\
\hline Federal & General- Summary & $\begin{array}{l}\text { Summary of U.S. } \\
\text { Agency Missions } \\
\text { and Capabilities in } \\
\text { Water } \\
\end{array}$ & $\begin{array}{l}\text { Water Supply } \\
\text { and Demand }\end{array}$ \\
\hline Federal & $\begin{array}{l}\text { US Forest } \\
\text { Service/USDA }\end{array}$ & $\begin{array}{l}\text { Climate Change and } \\
\text { Water Perspectives } \\
\text { from the Forest } \\
\text { Service }\end{array}$ & $\begin{array}{l}\text { Water Supply } \\
\text { and Demand }\end{array}$ \\
\hline Federal & $\begin{array}{l}\text { US Environmental } \\
\text { Protection Agency }\end{array}$ & \begin{tabular}{|l} 
Adaptation \\
Examples: Water \\
Resources
\end{tabular} & $\begin{array}{l}\text { Water Supply } \\
\text { and Demand }\end{array}$ \\
\hline Federal & $\begin{array}{l}\text { US Environmental } \\
\text { Protection Agency }\end{array}$ & $\begin{array}{l}\text { Water, Climate } \\
\text { Change, and Forests }\end{array}$ & $\begin{array}{l}\text { Water Supply } \\
\text { and Demand }\end{array}$ \\
\hline Federal & $\begin{array}{l}\text { Natural Resources } \\
\text { Defense Council }\end{array}$ & $\begin{array}{l}\text { Water Management } \\
\text { Strategies to } \\
\text { Weather the Effects } \\
\text { of Global Warming }\end{array}$ & $\begin{array}{l}\text { Water Supply } \\
\text { and Demand }\end{array}$ \\
\hline Federal & $\begin{array}{l}\text { Interagency Climate } \\
\text { Change Adaptation } \\
\text { Task Force }\end{array}$ & \begin{tabular}{|l} 
Priorities for \\
Managing \\
Freshwater \\
Resources in a \\
Changing Climate \\
\end{tabular} & $\begin{array}{l}\text { Water Supply } \\
\text { and Demand }\end{array}$ \\
\hline Federal & $\begin{array}{l}\text { U.S. Department of the } \\
\text { Interior U.S. Geological } \\
\text { Survey }\end{array}$ & $\begin{array}{l}\text { Climate Change and } \\
\text { Water Resources } \\
\text { Management: A } \\
\text { Federal Perspective }\end{array}$ & $\begin{array}{l}\text { Water Supply } \\
\text { and Demand }\end{array}$ \\
\hline Federal & $\begin{array}{l}\text { U.S. Department of the } \\
\text { Interior }\end{array}$ & $\begin{array}{l}\text { RECLAMATION } \\
\text { Colorado River } \\
\text { Basin Managing } \\
\text { Water in the West } \\
\end{array}$ & $\begin{array}{l}\text { Water Supply } \\
\text { and Demand }\end{array}$ \\
\hline Federal & National Ocean Council & \begin{tabular}{|l} 
NATIONAL \\
OCEAN POLICY \\
IMPLEMENTATIO \\
N PLAN \\
\end{tabular} & $\begin{array}{l}\text { Water Supply } \\
\text { and Demand }\end{array}$ \\
\hline
\end{tabular}




\begin{tabular}{|c|c|c|c|}
\hline Federal & USDA, NRCS & $\begin{array}{l}\text { National Watershed } \\
\text { Program Handbook }\end{array}$ & $\begin{array}{l}\text { Water Supply } \\
\text { and Demand }\end{array}$ \\
\hline Federal & USGS & $\begin{array}{l}\text { USGS Climate \& } \\
\text { Land Use Change } \\
\text { programs }\end{array}$ & $\begin{array}{l}\text { Water Supply } \\
\text { and Demand }\end{array}$ \\
\hline Federal & NOAA & $\begin{array}{l}\text { FORESTS AND } \\
\text { FOREST } \\
\text { ECOSYSTEMS }\end{array}$ & $\begin{array}{l}\text { Forest and } \\
\text { Grassland } \\
\text { Ecosystems }\end{array}$ \\
\hline Federal & $\begin{array}{l}\text { US Environmental } \\
\text { Protection Agency }\end{array}$ & $\begin{array}{l}\text { Adaptation } \\
\text { Examples: Forests }\end{array}$ & $\begin{array}{l}\text { Forest and } \\
\text { Grassland } \\
\text { Ecosystems }\end{array}$ \\
\hline Federal & $\begin{array}{l}\text { US Forest } \\
\text { Service/USDA }\end{array}$ & $\begin{array}{l}\text { Forest Service } \\
\text { Strategic Framework } \\
\text { For Responding to } \\
\text { Climate Change }\end{array}$ & $\begin{array}{l}\text { Forest and } \\
\text { Grassland } \\
\text { Ecosystems }\end{array}$ \\
\hline Federal & & $\begin{array}{l}\text { Using Experience } \\
\text { and Science to } \\
\text { develop Adaptation } \\
\text { Actions for the } \\
\text { Grasslands }\end{array}$ & $\begin{array}{l}\text { Forest and } \\
\text { Grassland } \\
\text { Ecosystems }\end{array}$ \\
\hline Federal & $\begin{array}{l}\text { US Forest } \\
\text { Service/USDA }\end{array}$ & $\begin{array}{l}\text { Responding to } \\
\text { Climate Change in } \\
\text { National Forests: A } \\
\text { Guidebook for } \\
\text { Developing } \\
\text { Adaptation Options }\end{array}$ & $\begin{array}{l}\text { Forest and } \\
\text { Grassland } \\
\text { Ecosystems }\end{array}$ \\
\hline Federal & & $\begin{array}{l}\text { Forest Adaptation } \\
\text { Strategies and } \\
\text { Actions }\end{array}$ & $\begin{array}{l}\text { Forest and } \\
\text { Grassland } \\
\text { Ecosystems }\end{array}$ \\
\hline Federal & & $\begin{array}{l}\text { Climate change } \\
\text { effects and } \\
\text { adaptation options } \\
\text { for forest ecosystems } \\
\text { in the west }\end{array}$ & $\begin{array}{l}\text { Forest and } \\
\text { Grassland } \\
\text { Ecosystems }\end{array}$ \\
\hline Federal & $\begin{array}{l}\text { Great Plains Landscape } \\
\text { Conservation } \\
\text { Cooperative }\end{array}$ & $\begin{array}{l}\text { Great Plains } \\
\text { Landscape } \\
\text { Conservation } \\
\text { Cooperative Action } \\
\text { Plan }\end{array}$ & $\begin{array}{l}\text { Forest and } \\
\text { Grassland } \\
\text { Ecosystems }\end{array}$ \\
\hline Federal & $\begin{array}{l}\text { U.S. Department of the } \\
\text { Interior }\end{array}$ & $\begin{array}{l}\text { Understanding the } \\
\text { Science of Climate } \\
\text { Change }\end{array}$ & $\begin{array}{l}\text { Forest and } \\
\text { Grassland } \\
\text { Ecosystems }\end{array}$ \\
\hline Federal & $\begin{array}{l}\text { U.S. Department of the } \\
\text { Interior }\end{array}$ & $\begin{array}{l}\text { Understanding the } \\
\text { Science of Climate } \\
\text { Change Talking }\end{array}$ & $\begin{array}{l}\text { Forest and } \\
\text { Grassland } \\
\text { Ecosystems }\end{array}$ \\
\hline
\end{tabular}




\begin{tabular}{|c|c|c|c|}
\hline & & $\begin{array}{l}\text { Points: Impacts to } \\
\text { Prairie Potholes and } \\
\text { Grasslands }\end{array}$ & \\
\hline Federal & $\begin{array}{l}\text { U.S. Department of the } \\
\text { Interior }\end{array}$ & $\begin{array}{l}\text { Understanding the } \\
\text { Science of Climate } \\
\text { Change Talking } \\
\text { Points: Impacts to } \\
\text { Western Mountains } \\
\text { and Forests }\end{array}$ & $\begin{array}{l}\text { Forest and } \\
\text { Grassland } \\
\text { Ecosystems }\end{array}$ \\
\hline Federal & $\begin{array}{l}\text { US Forest } \\
\text { Service/USDA }\end{array}$ & $\begin{array}{l}\text { Climate Change } \\
\text { Adaptation Plan }\end{array}$ & $\begin{array}{l}\text { Forest and } \\
\text { Grassland } \\
\text { Ecosystems }\end{array}$ \\
\hline Federal & $\begin{array}{l}\text { US Forest } \\
\text { Service/USDA }\end{array}$ & $\begin{array}{l}\text { Effects of Climatic } \\
\text { Variability and } \\
\text { Change on Forest } \\
\text { Ecosystems: A } \\
\text { Comprehensive } \\
\text { Science Synthesis } \\
\text { for the U.S. Forest } \\
\text { Sector }\end{array}$ & $\begin{array}{l}\text { Forest and } \\
\text { Grassland } \\
\text { Ecosystems }\end{array}$ \\
\hline Federal & $\begin{array}{l}\text { US Forest } \\
\text { Service/USDA }\end{array}$ & $\begin{array}{l}\text { Forest Service } \\
\text { Strategic Framework } \\
\text { For Responding to } \\
\text { Climate Change }\end{array}$ & $\begin{array}{l}\text { Forest and } \\
\text { Grassland } \\
\text { Ecosystems }\end{array}$ \\
\hline Federal & $\begin{array}{l}\text { US Forest } \\
\text { Service/USDA }\end{array}$ & $\begin{array}{l}\text { Forest management } \\
\text { for mitigation and } \\
\text { adaptation to climate } \\
\text { change: Insights } \\
\text { from long-term } \\
\text { silviculture } \\
\text { experiments }\end{array}$ & $\begin{array}{l}\text { Forest and } \\
\text { Grassland } \\
\text { Ecosystems }\end{array}$ \\
\hline Federal & National Park Service & $\begin{array}{l}\text { Strategies for } \\
\text { Coastal Park } \\
\text { Adaptation to } \\
\text { Climate Change }\end{array}$ & $\begin{array}{l}\text { Drought and } \\
\text { Flood Planning }\end{array}$ \\
\hline Federal & $\begin{array}{l}\text { National Drought } \\
\text { Mitigation Center }\end{array}$ & $\begin{array}{l}\text { Capabilities, Needs, } \\
\text { Activities: Missouri } \\
\text { River Basin } \\
\text { Applications }\end{array}$ & $\begin{array}{l}\text { Drought and } \\
\text { Flood Planning }\end{array}$ \\
\hline Federal & $\begin{array}{l}\text { US Department of } \\
\text { Defense }\end{array}$ & $\begin{array}{l}\text { Navy Task Force } \\
\text { Assesses Changing } \\
\text { Climate }\end{array}$ & $\begin{array}{l}\text { Drought and } \\
\text { Flood Planning }\end{array}$ \\
\hline Federal & USDA & $\begin{array}{l}\text { Prepare Your Farm } \\
\text { or Ranch Before } \\
\text { Drought Strikes }\end{array}$ & $\begin{array}{l}\text { Drought and } \\
\text { Flood Planning }\end{array}$ \\
\hline
\end{tabular}




\begin{tabular}{|c|c|c|c|}
\hline Federal & USDA & $\begin{array}{l}\text { Floods in a } \\
\text { Changing Climate }\end{array}$ & $\begin{array}{l}\text { Drought and } \\
\text { Flood Planning }\end{array}$ \\
\hline General & IPCC & $\begin{array}{l}\text { TECHNICAL } \\
\text { PAPER ON } \\
\text { CLIMATE } \\
\text { CHANGE AND } \\
\text { WATER }\end{array}$ & $\begin{array}{l}\text { Water Supply } \\
\text { and Demand }\end{array}$ \\
\hline New York & $\begin{array}{l}\text { New York State Sea } \\
\text { Level Rise Task Force }\end{array}$ & $\begin{array}{l}\text { ask Force Report to } \\
\text { the Legislature }\end{array}$ & $\begin{array}{l}\text { Drought and } \\
\text { Flood Planning }\end{array}$ \\
\hline \multirow[t]{3}{*}{ Wisconsin } & & $\begin{array}{l}\text { Chequamegon- } \\
\text { Nicolet National } \\
\text { Forest Climate } \\
\text { Change Assessments } \\
\text { \& Response } \\
\text { Framework }\end{array}$ & $\begin{array}{l}\text { Forest and } \\
\text { Grassland } \\
\text { Ecosystems }\end{array}$ \\
\hline & & $\begin{array}{l}\text { RESOURCE } \\
\text { MANAGEMENT } \\
\text { DURING } \\
\text { DROUGHT } \\
\text { ACTION PLAN }\end{array}$ & $\begin{array}{l}\text { Drought and } \\
\text { Flood Planning }\end{array}$ \\
\hline & & $\begin{array}{l}\text { Integrated Flood } \\
\text { Management - } \\
\text { Challenges and } \\
\text { Opportunities }\end{array}$ & $\begin{array}{l}\text { Drought and } \\
\text { Flood Planning }\end{array}$ \\
\hline
\end{tabular}




\section{Appendix C: NVivo screenshots}

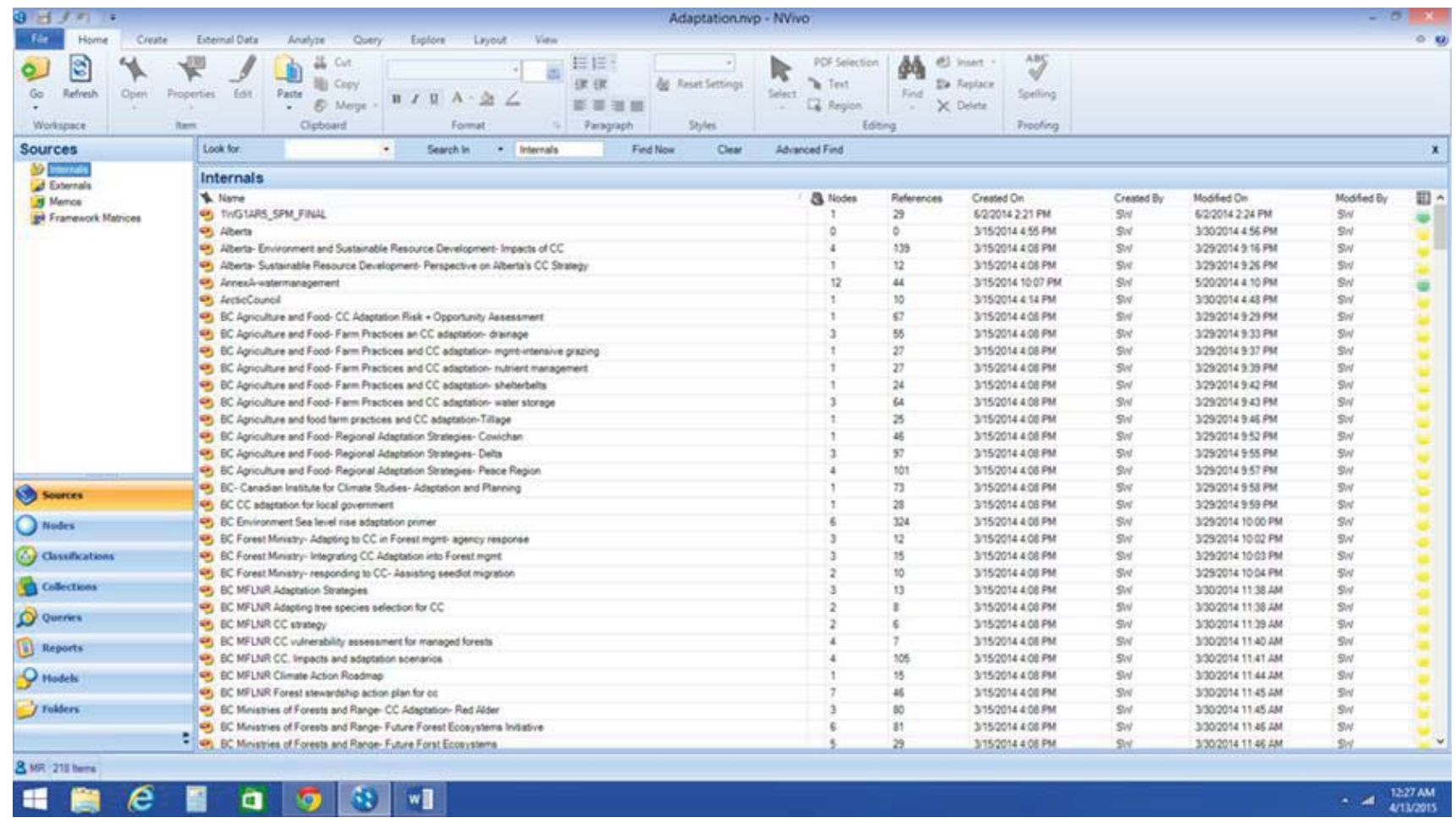

Screenshot 1: Nvivo desktop with all frameworks loaded in to the operating screen 


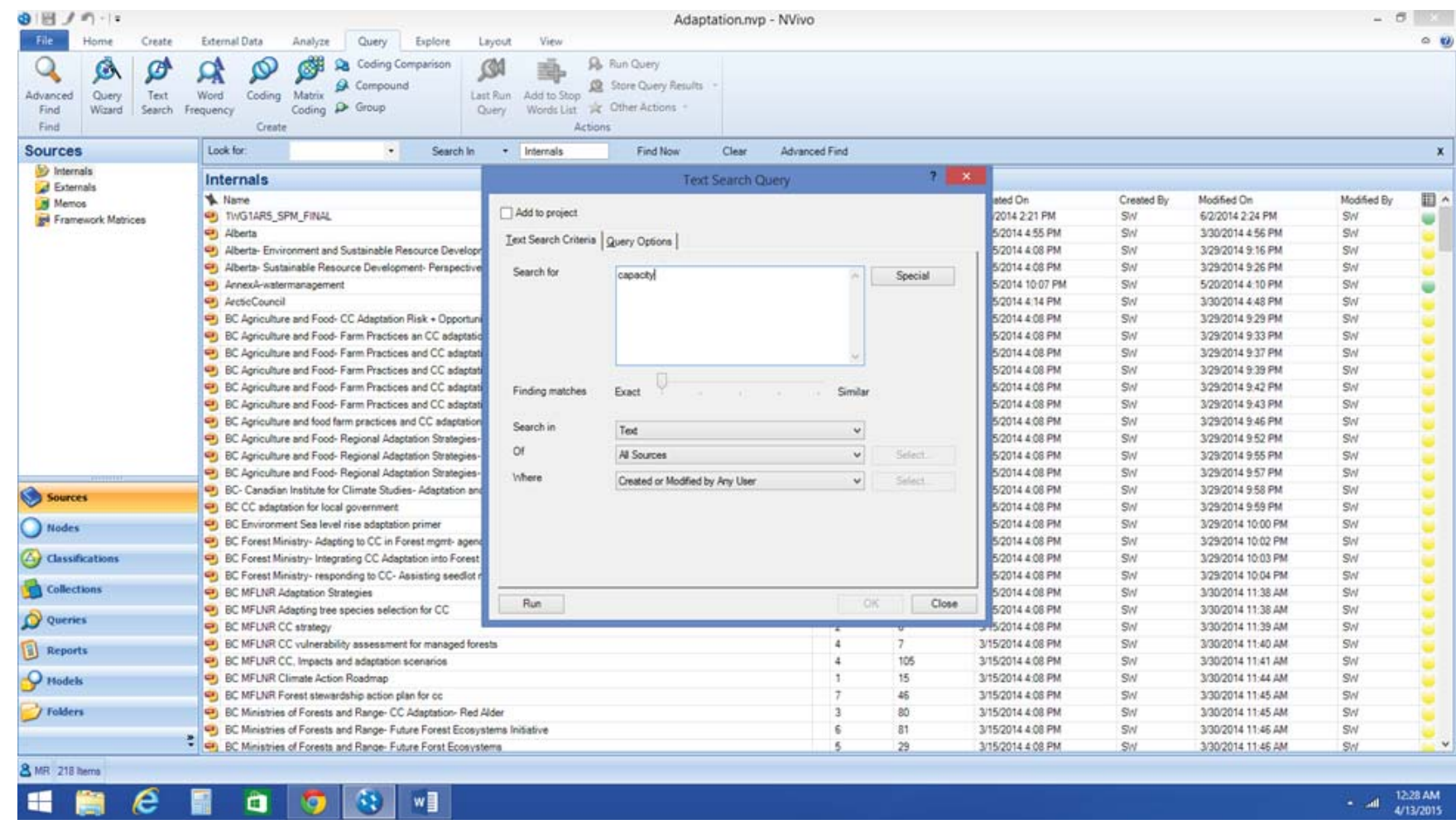

Screenshot 2: Searching for 'capacity' within the sources 


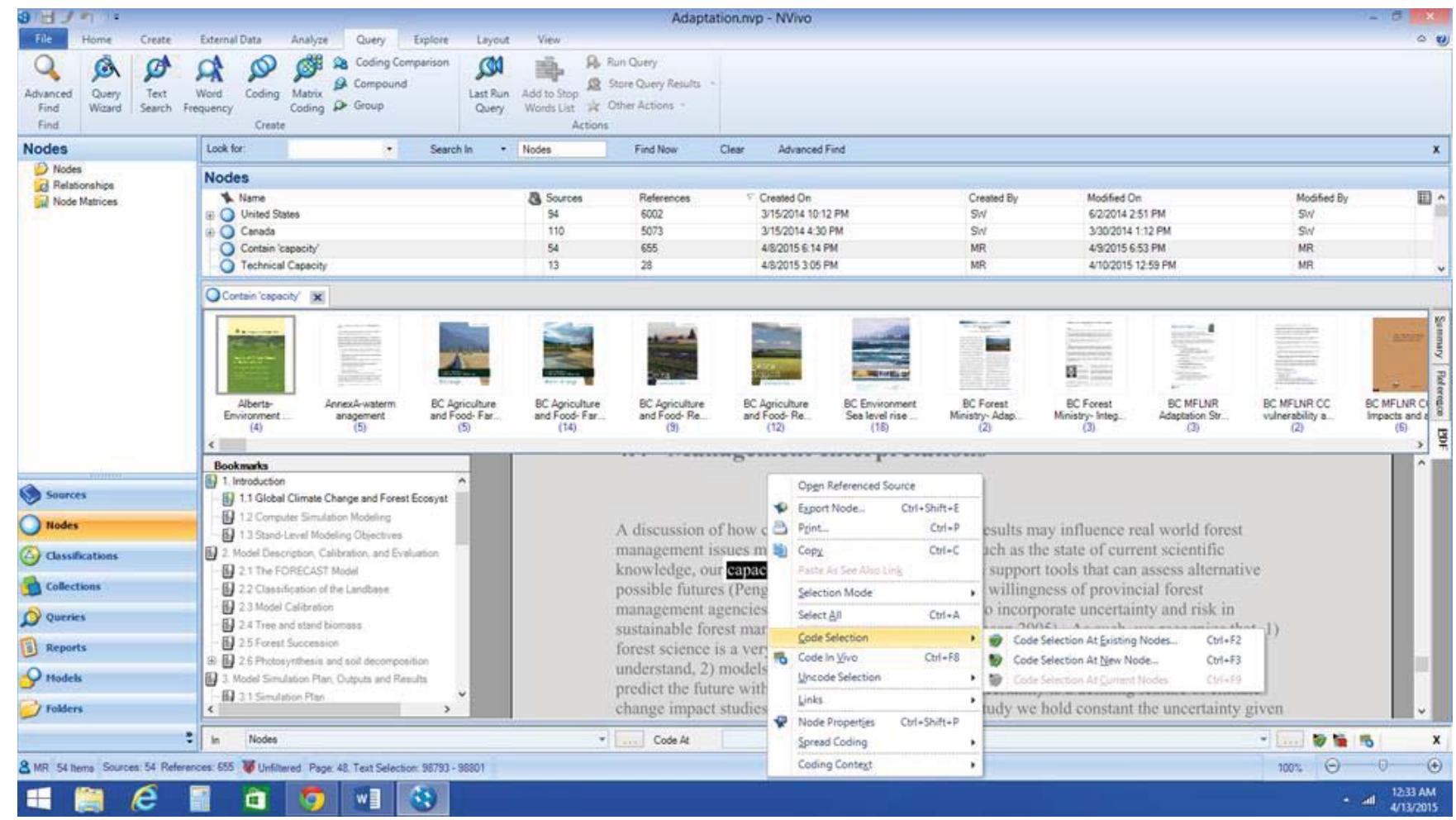

Screenshot 3: Coding selection at policy capacity node- Step 1 


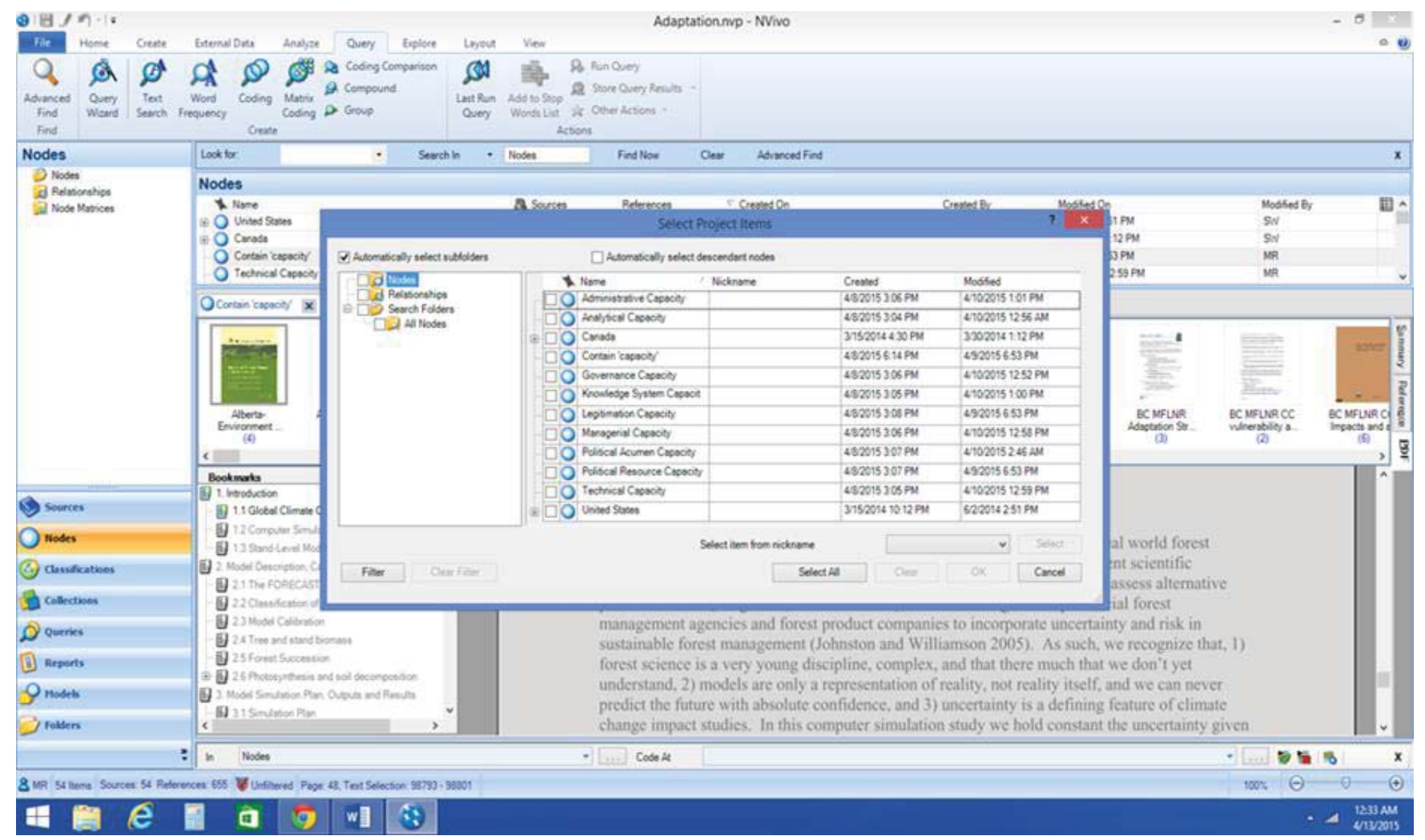

Screenshot 4: Coding selection at policy capacity node- Step 2 


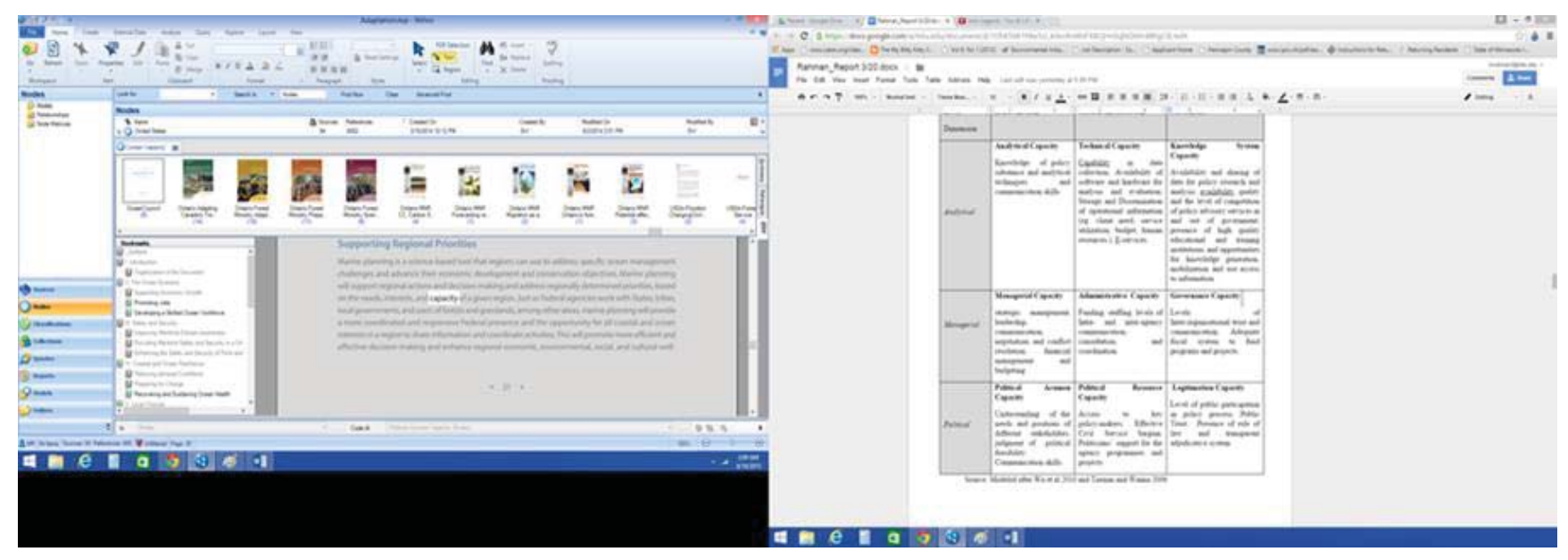

Screenshot 5: Deciphering which form of policy capacity is being referred to within the framework 